Ecosystem responses to reduced and oxidised nitrogen inputs in European terrestrial habitats

\author{
C.J. Stevens \\ P. Manning \\ L.J.L. van den Berg \\ M.C.C. de Graaf \\ G.W.W. Wamelink \\ A.W. Boxman
A. Bleeker
P. Vergeer \\ M. Arroniz-Crespo \\ J. Limpens \\ L.P.M. Lamers \\ R. Bobbink \\ E. Dorland
}


Review

\title{
Ecosystem responses to reduced and oxidised nitrogen inputs in European terrestrial habitats
}

\author{
Carly J. Stevens ${ }^{\mathrm{a}, \mathrm{b}, *}$, Pete Manning ${ }^{\mathrm{c}}$, Leon J.L. van den Berg ${ }^{\mathrm{d}, \mathrm{e}}$, Maaike C.C. de Graaf ${ }^{\mathrm{f}}$, \\ G.W. Wieger Wamelink ${ }^{\mathrm{g}}$, Andries W. Boxman ${ }^{\mathrm{e}}$, Albert Bleeker ${ }^{\mathrm{h}}$, Philippine Vergeer ${ }^{\mathrm{e}}$, \\ Maria Arroniz-Crespo ${ }^{\mathrm{i}}$, Juul Limpens ${ }^{\mathrm{j}}$, Leon P.M. Lamers ${ }^{\mathrm{e}}$, Roland Bobbink ${ }^{\mathrm{k}}$, Edu Dorland ${ }^{\mathrm{l}, \mathrm{m}}$ \\ ${ }^{a}$ Department of Life Sciences, The Open University, Walton Hall, Milton Keynes MK7 6AA, UK \\ ${ }^{\mathrm{b}}$ Lancaster Environment Centre, Lancaster University, Lancaster LA1 4YQ UK \\ ${ }^{\mathrm{C} S}$ Shool of Agriculture Food and Rural Development, Newcastle University, Newcastle Upon Tyne, Tyne E Wear NE1 7RU, UK \\ ${ }^{\mathrm{d}}$ Environment Department, University of York, Heslington, York YO10 5DD, UK \\ ${ }^{\mathrm{e}}$ Department of Aquatic Ecology and Environmental Biology, University of Nijmegen, P.O. Box 9010, Nijmegen NL-6500 GL, The Netherlands \\ ${ }^{\mathrm{f}}$ University of Applied Sciences, HAS Den Bosch, P.O. BOX 90108, 5200 MA's-Hertogenbosch, The Netherlands \\ ${ }^{g}$ Alterra, Droevendaalsesteeg 3a, P.O. Box 47, 6700 AA Wageningen, The Netherlands \\ ${ }^{\mathrm{h}}$ Energy Research Center of the Netherlands, Petten, NH, 1755 ZG, The Netherlands \\ ${ }^{i}$ Departamento de Biología Vegetal II, Facultad de Farmacia, Universidad Complutense de Madrid, 28040 Madrid, Spain \\ ${ }^{\mathrm{j}}$ Nature Conservation and Plant Ecology Group, Wageningen University, Bornsesteeg 69, 6708 PD Wageningen, The Netherlands \\ ${ }^{\mathrm{k}}$ B-Ware Research Centre, Radboud University Nijmegen, P.O. Box 9010, 6500 GL Nijmegen, The Netherlands \\ ${ }^{1}$ Staatsbosbeheer, P.O. Box 1300, 3970 BH Driebergen, The Netherlands \\ ${ }^{\mathrm{m}}$ KWR Watercycle Research Institute, P.O. Box 1072, 3430 BB Nieuwegein, The Netherlands \\ Changing ratios of $\mathrm{NH}_{x}$ and $\mathrm{NO}_{y}$ in deposition has important consequences for ecosystem function.
}

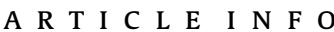

\section{Article history:}

Received 3 August 2010

Received in revised form

29 November 2010

Accepted 9 December 2010

\section{Keywords:}

Ammonium toxicity

Atmospheric nitrogen deposition

$\mathrm{NH}_{\mathrm{x}}: \mathrm{NO}_{\mathrm{y}}$ ratio

Mitigation

Nitrogen cycling

Nitrification

Plant communities

Soil acidification

\begin{abstract}
A B S T R A C T
While it is well established that ecosystems display strong responses to elevated nitrogen deposition, the importance of the ratio between the dominant forms of deposited nitrogen $\left(\mathrm{NH}_{\mathrm{x}}\right.$ and $\left.\mathrm{NO}_{\mathrm{y}}\right)$ in determining ecosystem response is poorly understood. As large changes in the ratio of oxidised and reduced nitrogen inputs are occurring, this oversight requires attention. One reason for this knowledge gap is that plants experience a different $\mathrm{NH}_{\mathrm{x}}: \mathrm{NO}_{\mathrm{y}}$ ratio in soil to that seen in atmospheric deposits because atmospheric inputs are modified by soil transformations, mediated by soil $\mathrm{pH}$. Consequently species of neutral and alkaline habitats are less likely to encounter high $\mathrm{NH}_{4}^{+}$concentrations than species from acid soils. We suggest that the response of vascular plant species to changing ratios of $\mathrm{NH}_{\mathrm{x}}: \mathrm{NO}_{\mathrm{y}}$ deposits will be driven primarily by a combination of soil $\mathrm{pH}$ and nitrification rates. Testing this hypothesis requires a combination of experimental and survey work in a range of systems.
\end{abstract}

(c) 2010 Elsevier Ltd. All rights reserved.

\section{Introduction}

Nitrogen (N) is essential for life as a component of amino acids, proteins, and DNA. Much N is present in the Earth's atmosphere, but almost all is in the unreactive form $\left(\mathrm{N}_{2}\right.$, gaseous $\left.\mathrm{N}\right)$. The reactive forms of $\mathrm{N}$ utilised by organisms ( $\mathrm{Nr}$ ) naturally enter ecosystems via biological $\mathrm{N}$ fixation (by legumes, cyanolichens or free-living bacteria), biomass burning, volcanic activity and lightning but

\footnotetext{
* Corresponding author.

E-mail address: c.j.stevens@open.ac.uk (C.J. Stevens).
}

human activities over the last century have more than doubled the inputs of $\mathrm{Nr}$ into the World's ecosystems. The result has been widespread changes to the global N cycle (e.g. Galloway et al., 2008). Most of this rise in atmospherically deposited $\mathrm{N}$ has been in the form of wet deposition, $\mathrm{N}$ which enters ecosystems via precipitation, and dry deposition, which is the direct input of atmospheric $\mathrm{N}$ gasses and aerosols by wind and gravity. These inputs take two main forms, reduced $\left(\mathrm{NH}_{\mathrm{x}}-\right.$ ammonia and ammonium) and oxidised ( $\mathrm{NO}_{\mathrm{y}}$ - nitrogen oxides, nitric acid and particulate nitrate) both of which can be deposited as wet or dry deposition depending on climate. For example, wet areas such as Scandinavia will be dominated by wet deposition whereas dry 
areas such as the Mediterranean will be dominated by dry deposition. In Europe and parts of North America, the deposition of $\mathrm{NH}_{\mathrm{x}}$ and $\mathrm{NO}_{\mathrm{y}}$ strongly increased in the second half of the 20th century, primarily due to increasing agricultural and industrial activities (Fowler et al., 2004; Fenn et al., 2003). Since the 1990s N deposition has also started increasing in eastern Asia and India and it is expected that this dramatic rise will continue in the coming decades (Galloway et al., 2008; Dentener, 2006).

Increased deposition of $\mathrm{N}$ can increase net primary productivity in some terrestrial ecosystems (LeBauer and Treseder, 2008) but it has also been demonstrated in both experimental (e.g. Mountford et al., 1993; Wilson et al., 1995; Bobbink et al., 1998) and observational studies (e.g. Stevens et al., 2004; Maskell et al., 2010; Dupré et al., 2010) that increasing $\mathrm{N}$ deposition reduces plant species richness, with lichens, bryophytes, low growing forbs and legumes being particularly sensitive (Bobbink and Lamers, 2002; Suding et al., 2005). The mechanisms underlying these changes are yet to be fully understood and, while light exclusion has been demonstrated to be the cause of $\mathrm{N}$ induced species losses in mesotrophic grasslands (Hautier et al., 2009), N inputs may also decrease diversity through factors such as nutrient imbalance, soil acidification, ammonium toxicity, and increased susceptibility to pests and frost (see Bobbink et al., 1998, 2010 and references herein).

There have been previous calls that both the amount (load and dose) and form of $\mathrm{N}$ inputs need to be considered when considering N deposition effects on ecosystems (e.g. Bobbink and Roelofs, 1995; Bobbink et al., 2003) but in almost all ecological studies of $\mathrm{N}$ deposition reduced and oxidised $\mathrm{N}$ are considered equivalent, with the total amount of $\mathrm{N}$ deposition assumed to determine ecosystem response (e.g. Stevens et al., 2004; Manning et al., 2006). Very few studies have investigated the impact of changing ratios of $\mathrm{NH}_{\mathrm{x}}$ and $\mathrm{NO}_{\mathrm{y}}$ inputs although a number of studies have investigated the differential effects of reduced and oxidised $\mathrm{N}$ on vegetation (e.g. Sanchez-Hoyos and Manrique, 1995; Pearce et al., 2003; Paulissen et al., 2004; Van den Berg et al., 2008; Hogan et al., 2010) with some studies showing different impacts for different $\mathrm{N}$ forms. In this paper we argue that the form of $\mathrm{N}$ deposition inputs has important consequences for ecosystem response to $\mathrm{N}$ enrichment, and that viewing $\mathrm{N}$ deposition loads as total inorganic $\mathrm{N}$ input may be insufficient to understand ecosystem responses to $\mathrm{N}$ deposition.

Firstly, we explore the spatial and temporal patterns of $\mathrm{NH}_{\mathrm{x}}$ and $\mathrm{NO}_{\mathrm{y}}$ inputs (Section 2), the effects of changing $\mathrm{NH}_{\mathrm{x}}$ and $\mathrm{NO}_{\mathrm{y}}$ inputs and $\mathrm{NH}_{\mathrm{x}}: \mathrm{NO}_{\mathrm{y}}$ ratios on soil processes and biogeochemical cycling, and discuss how these changes influence the $\mathrm{NH}_{\mathrm{x}}: \mathrm{NO}_{\mathrm{y}}$ ratio which plants are exposed to in European terrestrial habitats (Section 3). We synthesise findings on plant species differences in their preference and tolerance of these two $\mathrm{N}$ forms (Section 4), identify situations where $\mathrm{NH}_{\mathrm{x}}: \mathrm{NO}_{\mathrm{y}}$ ratio needs to be considered when explaining community-level responses to $\mathrm{N}$ deposition, and make predictions regarding these community responses (Section 5). Finally, we discuss the science required to confirm these predictions and the implications of changing $\mathrm{NH}_{\mathrm{x}}: \mathrm{NO}_{\mathrm{y}}$ ratios for biodiversity conservation and habitat management (Section 6). This review will focus on the impacts of the changing inputs and ratios of $\mathrm{N}$ deposition in European terrestrial habitats because they have been most intensively studied. While we do not expect the mechanistic basis to change, translating our hypotheses to areas of the world not covered by our data (e.g. South America, East Asia and East Africa) must be treated with caution.

\section{The cause of differences in $\mathbf{N}$ input ratios}

There are considerable differences in the temporal and spatial patterns of $\mathrm{NH}_{\mathrm{x}}$ and $\mathrm{NO}_{\mathrm{y}}$ emissions (Holland et al., 2005), and there is evidence that ratios of reduced to oxidised $\mathrm{N}$ deposition are changing at regional scales as a result of land use, technology and policy changes.

Nitrogen oxides $\left(\mathrm{NO}_{\mathrm{y}}\right)$ are emitted mainly from stationary combustion sources (industrial processes and power plants) and transport activities (road and ship traffic), while reduced $\mathrm{N}\left(\mathrm{NH}_{\mathrm{X}}\right)$ emissions are mostly a result of agricultural activities such as animal husbandry (livestock wastes) and fertiliser application (e.g. Asman et al., 1998; Holland et al., 2005). Because of the differences in sources and their distribution, atmospheric transformations and deposition velocities, clear regional $\mathrm{N}$ deposition patterns have been observed. In general, total $\mathrm{N}$ deposition is spatially highly variable, with the highest deposition rates often dominated by dry deposition of $\mathrm{NH}_{3}$ close to its source, and declining rapidly with distance (see Stevens and Tilman (2010) for an example). In contrast, wet deposition of both $\mathrm{NH}_{\mathrm{x}}$ and $\mathrm{NO}_{\mathrm{y}}$ and dry deposition of $\mathrm{NO}_{\mathrm{y}}$ display less spatial variability, as a result of the diffuse and point source origins of these two forms of pollutant. The result of this variability is spatial heterogeneity in the pattern of $\mathrm{NO}_{\mathrm{y}}$ and $\mathrm{NH}_{\mathrm{X}}$ deposition at a local scale (Sutton et al., 1998).

This local variability is nested within large scale patterns of $\mathrm{N}$ deposition. In western Europe, the highest values were observed in the 1980s and 1990s, with hot spots of $\mathrm{NH}_{\mathrm{x}}$ deposition ( $>70 \%$ of total deposition) in intensively farmed regions such as Netherlands, Belgium, Denmark, north-west Germany and Italy's Po Valley. Contrary to this, $\mathrm{NO}_{\mathrm{y}}$ deposition peaked in the 1980s in parts of Eastern Europe (Van Leeuwen et al. 1996). Over Europe as a whole $\mathrm{NO}_{\mathrm{y}}$ deposition decreased between 1990 and 2005 as a result of a change from coal burning to gas or nuclear power, while $\mathrm{NH}_{\mathrm{x}}$ deposition stabilised after 1995, resulting in an increased $\mathrm{NH}_{\mathrm{x}}: \mathrm{NO}_{\mathrm{y}}$ ratio (Fagerli and Aas, 2008). Significant differences in the input of $\mathrm{NO}_{\mathrm{y}}$ and $\mathrm{NH}_{\mathrm{x}}$ are even seen at the continental scale. In the 1990s the $\mathrm{NH}_{\mathrm{x}}: \mathrm{NO}_{\mathrm{y}}$ ratio for the USA was 0.64 , in contrast to 1.02 in Europe and 2.48 in Asia as a result of different energy production, farming and waste management practices (Galloway et al., 2004; Fig. 1).

Galloway et al. (2004) predict that by 2050 terrestrial $\mathrm{NO}_{\mathrm{y}}$ deposits will have increased by up to $70 \%$ from levels in the 1990 s, while $\mathrm{NH}_{\mathrm{x}}$ deposits will increase by $133 \%$ over the same period primarily due to increased demand for food. This trend towards increased $\mathrm{NH}_{\mathrm{x}}$ deposits relative to those of $\mathrm{NO}_{\mathrm{y}}$ is already being observed in Europe (Fagerli and Aas, 2008). However, in the Netherlands $\mathrm{NH}_{\mathrm{x}}$ deposition has decreased considerably through legislation, which significantly reduced $\mathrm{NH}_{\mathrm{x}}$ emissions. Detailed measurements from a Dutch pine forest have shown that $\mathrm{NH}_{4}^{+}$ deposition in throughfall decreased by $40 \%$ since 1984 , while $\mathrm{NO}_{3}^{-}$ deposition increased, resulting in significant decrease in throughfall $\mathrm{NH}_{4}^{+}: \mathrm{NO}_{3}^{-}$ratio. At the same time, the $\mathrm{NH}_{4}^{+}: \mathrm{NO}_{3}^{-}$ratio in the mineral soil solution at $10 \mathrm{~cm}$ depth also decreased (Fig. 2; Boxman et al., 2008), indicating that changes in the ratio of deposits may be experienced by plant roots.

\section{Factors controlling plant responses}

After deposition, $\mathrm{N}$ is affected by a number of factors, influencing the ratio of reduced and oxidised $\mathrm{N}$ that plants are exposed to (Fig. 3). Where plants take up $\mathrm{N}$ via their leaves, the $\mathrm{NH}_{\mathrm{x}}: \mathrm{NO}_{\mathrm{y}}$ ratio they experience will often be similar to atmospheric $\mathrm{N}$ deposits. In contrast, $\mathrm{N}$ deposits to the soil may be strongly modified by chemical and biological transformations in the heterogeneous soil environment, and so soil $\mathrm{NH}_{\mathrm{x}}$ : $\mathrm{NO}_{\mathrm{y}}$ ratios may be very different to those of $\mathrm{N}$ deposits (Fig. 3).

\subsection{Stratification by vegetation}

Spatial patterns of reduced and oxidised $\mathrm{N}$ deposition, and the relative abundances of these two forms, will be modified at local 

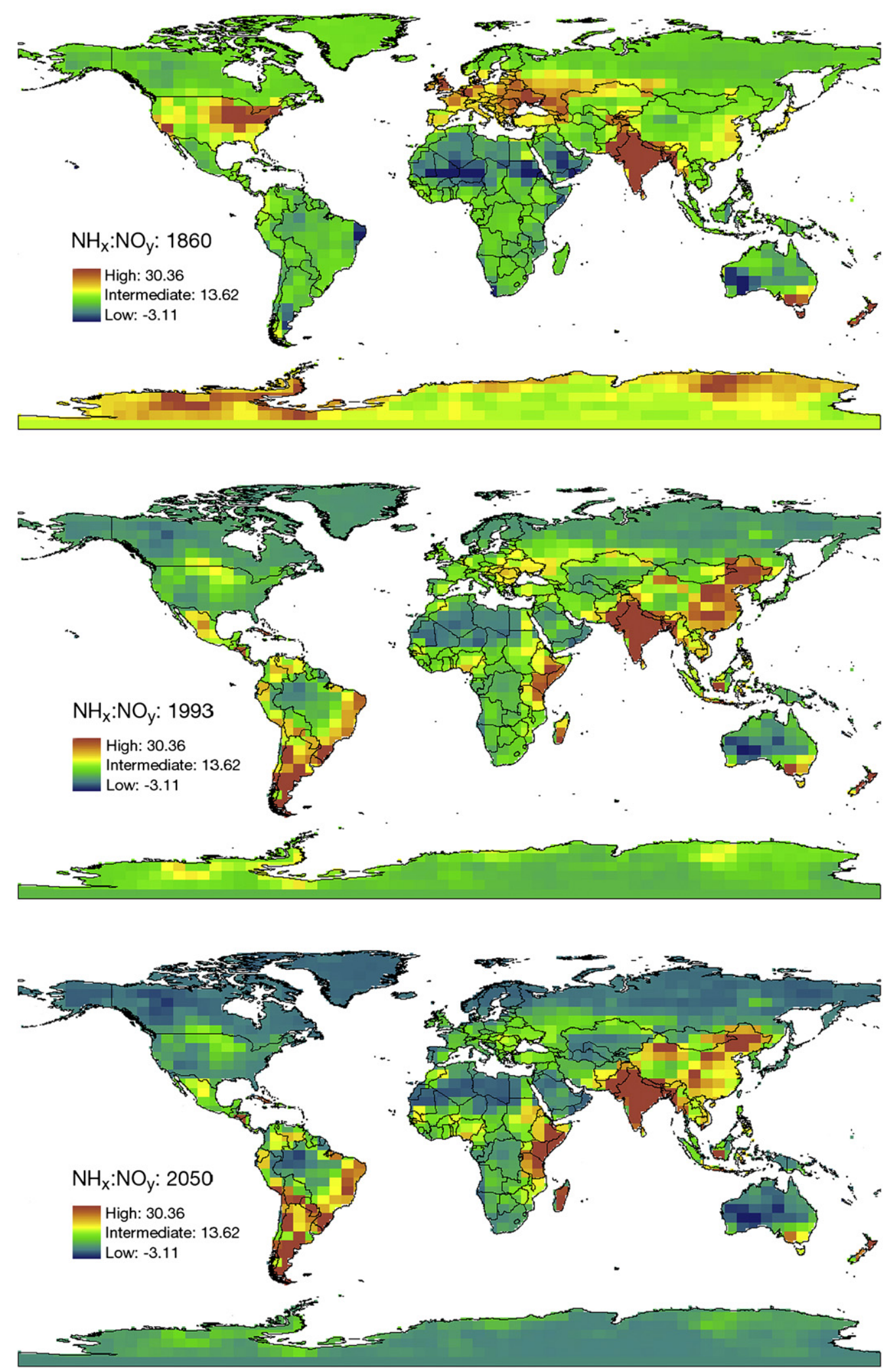

Fig. 1. Ratio between modelled $\mathrm{NH}_{\mathrm{x}}$ and $\mathrm{NO}_{\mathrm{y}}$ deposits (by mass $\mathrm{NH}_{4}-\mathrm{N}$ : $\mathrm{NO}_{3}-\mathrm{N}$ ) for 1860, 1993 and 2050. Data were taken from the modelled output of Dentener, 2006.

scales by vegetation structure (e.g. Fangmeier et al., 1994) and soil conditions. For example, dry deposition of $\mathrm{N}$ onto vegetation with a rough canopy structure, e.g. coniferous forest, is considerably higher $(>50 \%)$ than that onto smooth surfaces, e.g. a calcareous grassland. Moreover, the roughness of the vegetation may also influence the $\mathrm{NH}_{\mathrm{x}}: \mathrm{NO}_{\mathrm{y}}$ ratio of deposited $\mathrm{N}$. In coniferous and deciduous forests $\mathrm{NH}_{\mathrm{x}}: \mathrm{NO}_{\mathrm{y}}$ ratios in open field precipitation and throughfall are approximately of the same order of magnitude 


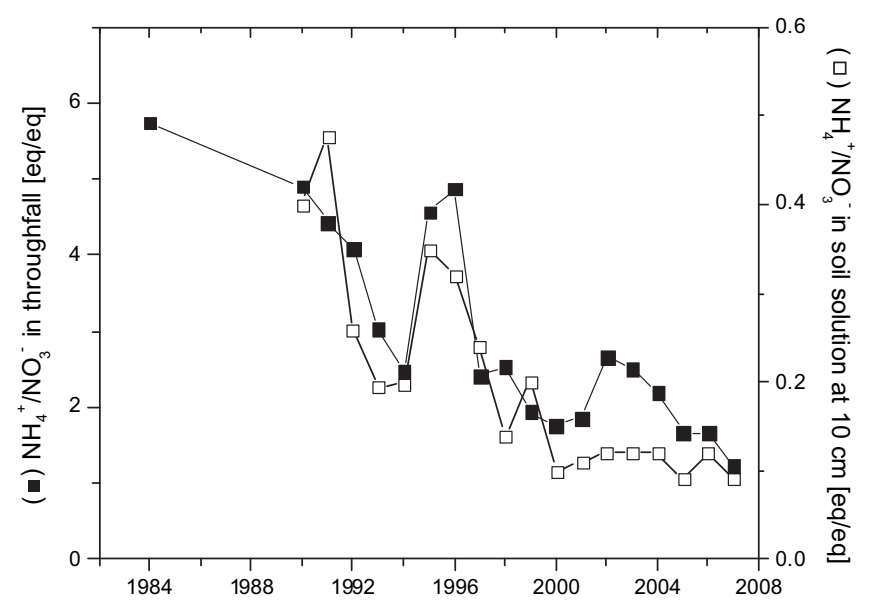

Fig. 2. Ground measurements of $\mathrm{NH}_{\mathrm{x}}: \mathrm{NO}_{\mathrm{y}}$ ratio in throughfall, and in the mineral soil at $10 \mathrm{~cm}$ depth [eq/eq] in a Dutch Pine forest. Original data source: Boxman et al., 2008.

(Berger et al., 2008). In (grass-dominated) heathlands there are indications that the $\mathrm{NH}_{\mathrm{x}}: \mathrm{NO}_{\mathrm{y}}$ ratio in throughfall is much lower than that of open field precipitation. The latter is solely due to lower $\mathrm{NH}_{\mathrm{x}}$ concentrations, with $\mathrm{NO}_{\mathrm{y}}$ concentrations remaining unaltered, indicating preferential foliar uptake of $\mathrm{NH}_{\mathrm{x}}$ (De Schrijver et al., 2008). Modification of $\mathrm{NH}_{\mathrm{x}}: \mathrm{NO}_{\mathrm{y}}$ ratios also occurs in some mossdominated ecosystems, where the preferential uptake and sequestration of $\mathrm{NH}_{4}^{+}$in the moss carpet (Wiedermann et al., 2009) regulates the soil $\mathrm{NH}_{\mathrm{x}}: \mathrm{NO}_{\mathrm{y}}$ ratio that is experienced in the rhizosphere of vascular plants (Lamers et al., 2000; Limpens et al., 2003).

\subsection{Soil processes affecting $\mathrm{NH}_{x}: \mathrm{NO}_{y}$ ratio}

In the soil, gaseous forms of $\mathrm{NH}_{\mathrm{x}}$ and $\mathrm{NO}_{\mathrm{y}}$ dissolve readily to form $\mathrm{NH}_{4}^{+}$and $\mathrm{NO}_{3}^{-}$. Typically most $\mathrm{NO}_{3}^{-}$is either taken up by plants and microbes, with a small portion denitrified. Unlike $\mathrm{NO}_{3}^{-}$, $\mathrm{NH}_{4}^{+}$can bind strongly to soil cation exchange sites, resulting in soil $\mathrm{NH}_{4}^{+}$accumulation (Fig. 3). In the soil solution, however, plant roots will experience changes in the $\mathrm{NH}_{\mathrm{x}}: \mathrm{NO}_{\mathrm{y}}$ ratio that will influence plant and soil properties, including transformations of $\mathrm{N}$ within the soil. All of these effects will be modified by the existing properties of the soil (derived primarily from the type of bedrock), such as its buffer capacity, $\mathrm{pH}$, redox potential, microbial community composition, and climate. However, due to complex interactions between these soil properties it may prove difficult to predict general effects of changing $\mathrm{NH}_{\mathrm{x}}: \mathrm{NO}_{\mathrm{y}}$ ratios on soil $\mathrm{N}$ availability.

While the effect of $\mathrm{NH}_{\mathrm{x}}: \mathrm{NO}_{\mathrm{y}}$ ratio on decomposition and mineralisation is poorly known, both direct effects on the activity and abundance of dominant decomposer groups and indirect effects through litter quality are to be expected. For example, increased $\mathrm{N}$ input most often stimulates the initial stages of litter decomposition, in which easily degradable materials are consumed by microbes, but suppresses later decomposition stages, in which recalcitrant C is 'mined' for nitrogen (Berg and Matzner, 1997; Knorr et al., 2005); however, exceptions to occur (e.g. Keeler et al., 2009 found no or negative effects on overall rates of litter and organic matter decomposition). The strength of such effects may differ depending on the form of deposited N. DeForest et al. (2004) found chronic $\mathrm{NO}_{3}^{-}$additions did not alter the microbial community composition but broadly suppressed all microbial groups which may also impact soil processes. Indirect effects may also occur through changes in plant litter quality (see Section 4.1). The resulting changes to decomposition and $\mathrm{N}$ mineralisation rates may subsequently lead to differences in the amount and form of $\mathrm{N}$ available to plants. Initial evidence for such effects is provided by Currey et al. (2010), who found that potential mineralisation of labile carbon was higher under $\mathrm{NH}_{4}^{+}$addition than under $\mathrm{NO}_{3}^{-}$ addition in peat soils. In the same study it was also shown that consumption of the amino acid glutamic acid was higher under $\mathrm{NH}_{4}^{+}$than $\mathrm{NO}_{3}^{-}$addition.

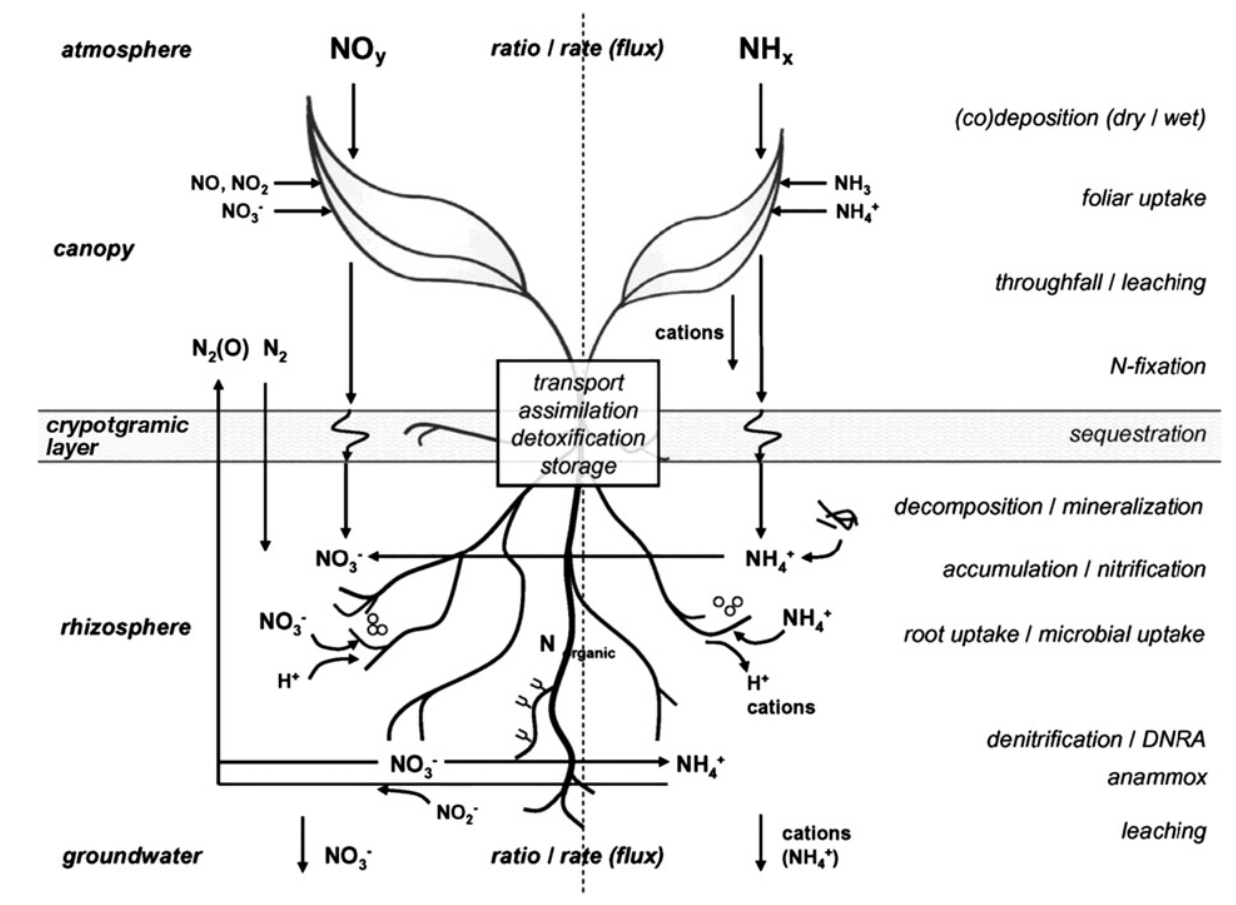

Fig. 3. Processes influencing the availability and ratio of oxidised $\left(\mathrm{NO}_{\mathrm{y}}\right)$ and reduced $\left(\mathrm{NH}_{\mathrm{x}}\right)$ nitrogen forms which plants are exposed to DNRA: dissimilatory nitrate reduction to ammonium, anammox: anaerobic ammonium oxidation. 


\subsubsection{Nitrification and denitrification}

The ratio of $\mathrm{NH}_{\mathrm{x}}$ and $\mathrm{NO}_{\mathrm{y}}$ in soil is strongly influenced by the activity of nitrifying, ammonia oxidizing bacteria (AOB). Nitrification itself is also affected by several soil factors including availability of $\mathrm{NH}_{4}^{+}$(the sole energy source for autotrophic nitrifying bacteria, Booth et al., 2005), $\mathrm{pH}, \mathrm{O}_{2}$ availability (and factors influencing $\mathrm{O}_{2}$ diffusion through soil such as soil structure), temperature, soil moisture, C:N ratio (e.g. Vestgarden and Kjønaas, 2003) and DOC: $\mathrm{NO}_{3}^{-}$ratios (Taylor and Townsend, 2010). It is very likely that soil nitrifying activity will increase with increased $\mathrm{NH}_{4}^{+}$availability (in absolute or relative terms), but the magnitude of this increase may depend on soil $\mathrm{pH}$ and soil aeration, which are often correlated. In various ecosystems, such as grasslands and heathlands, nitrification is inhibited at low soil $\mathrm{pH}$, resulting in $\mathrm{NH}_{4}^{+}$ accumulation (e.g. Roelofs et al., 1985; Dorland et al., 2004). Since nitrification yields protons, it reduces $\mathrm{pH}$ and so constitutes a negative feedback, reducing nitrification. As a result high $\mathrm{NH}_{4}^{+}$ inputs can acidify the soil and limit future nitrification. In other ecosystems such as forests, nitrification may depend less on soil $\mathrm{pH}$ (Booth et al., 2005) or can even be high despite low soil pH, as has been reported for some mature forests (Houdijk et al., 1993). Nitrification also depends on the presence and abundance of the initial bacterial community structure. For example, elevated $\mathrm{NH}_{\mathrm{y}}$ concentrations result in increased nitrification rates in the presence of $\mathrm{NH}_{\mathrm{y}}$-tolerant $\mathrm{AOB}$, whereas nitrification will be delayed (or even inhibited) when $\mathrm{NH}_{\mathrm{y}}$-sensitive $\mathrm{AOB}$ dominate (Prosser, 1989; Webster et al., 2005). In summary, higher $\mathrm{NH}_{\mathrm{x}}: \mathrm{NO}_{\mathrm{y}}$ ratios in $\mathrm{N}$ deposition will only lead to increased ratios of plant-available $\mathrm{NH}_{4}^{+}: \mathrm{NO}_{3}^{-}$ratios in soils with low nitrification rates. These soils are characterized by initially low $\mathrm{NH}_{4}^{+}$and low $\mathrm{O}_{2}$ availability, low pH, and very low or very high soil moisture levels (Booth et al., 2005). In soils with high nitrification rates a high ratio of $\mathrm{NH}_{\mathrm{x}}: \mathrm{NO}_{\mathrm{y}}$ deposits is less likely to be retained in the soils. This conversion of $\mathrm{NH}_{\mathrm{x}}$ to $\mathrm{NO}_{\mathrm{y}}$ lessens the threat of $\mathrm{NH}_{\mathrm{x}}$ toxicity to plants (see below) but poses a greater risk of problems associated with acidification, and $\mathrm{NO}_{\mathrm{y}}$ pollution in groundwater and runoff.

In general, the anaerobic processes denitrification (the conversion of $\mathrm{NO}_{3}^{-}$to $\mathrm{NO}, \mathrm{N}_{2} \mathrm{O}$ and $\mathrm{N}_{2}$ ) and DNRA (Dissimilatory Nitrate Reduction to Ammonium, i.e. the conversion of $\mathrm{NO}_{3}^{-}$into $\mathrm{NO}_{2}$ and subsequently to $\mathrm{NH}_{4}^{+}$) play a minor role in well-aerated soils (e.g. De Klein and Van Logtestijn, 1996; Stevens et al., 1998). Consequently, plant-available $\mathrm{NH}_{4}^{+}: \mathrm{NO}_{3}^{-}$ratios in soils of temperate European grasslands, heathland and forests will be largely unaffected by these microbial processes. In wetlands however, denitrification and DNRA may play a major role in removing excess $\mathrm{NO}_{3}^{-}$from the soil. Once the supply of $\mathrm{NO}_{3}^{-}$from either atmosphere or nitrification decreases, denitrification and DNRA rates drop (Paavolainen and Smolander, 1998; Silver et al., 2001; Sanchez-Martin et al., 2008), resulting in accumulation of $\mathrm{NH}_{4}^{+}$and high $\mathrm{NH}_{4}^{+}: \mathrm{NO}_{3}^{-}$ratios. We hypothesize that in wetlands with low nitrification rates (i.e. with low soil redox potential and low availability of carbon and $\mathrm{O}_{2}$ ), increasing $\mathrm{NH}_{\mathrm{x}}$ : $\mathrm{NO}_{\mathrm{y}}$ ratios in $\mathrm{N}$ deposition leads to lower denitrification and DRNA activity and accumulation of $\mathrm{NH}_{4}^{+}$.

\subsection{Interaction with other elements and acidification}

Besides differential effects on microbial processes, the dominant form of inorganic soil $\mathrm{N}$ also affects several other soil properties affecting plant performance. Increased $\mathrm{NH}_{4}^{+}$deposition may directly and indirectly affect the concentration of essential base cations, such as $\mathrm{K}^{+}, \mathrm{Mg}^{2+}$ and $\mathrm{Ca}^{2+}$, by replacing them on the cation exchange sites in the soil, or by depressing base cation uptake by plants, particularly at low pH (Boxman et al., 1991; Gloser and Gloser, 2000). As a result, base cations are readily leached to deeper soil layers, potentially leading to base cation depletion or trace-element shortages.
Additionally, increased $\mathrm{NH}_{\mathrm{x}}$ deposition may lead to soil acidification via a number of pathways including nitrification, with two $\mathrm{H}^{+}$produced per mol N, exchange of $\mathrm{NH}_{4}^{+}$with $\mathrm{H}^{+}$at the soil complex, or by plant uptake of $\mathrm{NH}_{4}^{+}$(Fig. 3), particularly in weakly buffered soils. This acidification can in turn, reduce plant-available $\mathrm{N}$ and $\mathrm{N}$-uptake by plants and their symbionts through changes in the availability of heavy metals and aluminum (e.g. Lazof et al., 1994; Ghnaya et al., 2007).

\section{Plant responses}

\subsection{Root and foliar $N$ uptake}

Foliar (including bryophyte shoot system) N uptake (Fig. 3) can be significant in vascular plants, bryophytes and lichens, particularly in N-limited systems (e.g. Pérez-Soba and van der Eerden, 1993; Cape et al., 2009) and during periods of rapid growth when stomatal conductance is high (e.g. Wilson, 1992; Teklemariam and Sparks, 2004). Although many lichens capture both nitrate and ammonium equally under ambient concentrations (Hauck, 2010), in general, in vascular plants foliar uptake of $\mathrm{NH}_{\mathrm{x}}$ exceeds that of $\mathrm{NO}_{\mathrm{y}}$ (e.g. Garten and Hanson, 1990; Wilson, 1992; Lumme, 1994; Palmqvist and Dahlman, 2006). In an N-limited spruce forest, foliar $\mathrm{N}$ uptake was $\sim 90 \%$ for $\mathrm{NH}_{4}^{+}$and $\sim 75 \%$ for $\mathrm{NO}_{3}^{-}$(e.g. Sievering et al., 2007). Foliar $\mathrm{NH}_{4}^{+}$uptake is usually accompanied by an increase in base cation concentration in stem flow and throughflow, implying the loss of base cations from the foliage and potential risk of deficiencies of ions such as $\mathrm{K}^{+}, \mathrm{Mg}^{2+}, \mathrm{Ca}^{2+}$ and $\mathrm{Mn}^{2+}$ (Roelofs et al., 1987; Garten and Hanson, 1990; Bobbink et al., 1992; De Schrijver et al., 2008). In addition, foliar $\mathrm{NH}_{4}^{+}$ uptake affects cell $\mathrm{pH}$ regulation as ions (e.g. $\mathrm{H}^{+}$) are exchanged with the cell apoplasts, potentially resulting in cell acidification and problems relating to cell elongation and growth (Peuke et al., 1998; Paulissen et al., 2004; Van den Berg et al., 2005). In contrast, uptake and assimilation of reduced $\mathrm{N}$ by roots is usually accompanied by $\mathrm{H}^{+}$exchange with the rhizosphere (Fig. 3) preventing cell acidification, unless $\mathrm{pH}$ is low. Under such conditions, root uptake of $\mathrm{NH}_{4}^{+}$ may lead to cell acidification in non-adapted plant species, as these plants are not able to exude $\mathrm{H}^{+}$to the acid rhizosphere (Lucassen et al., 2003; Van den Berg et al., 2005). In contrast, uptake of $\mathrm{NO}_{3}^{-}$ by either shoots or roots has no consequences for cell $\mathrm{pH}$.

The rate and form of inorganic $\mathrm{N}$ uptake depends heavily upon both plant species and soil properties. Plants adapted to soils with low nitrification rates e.g. many slow growing and perennial groups including Ericaceae and conifers, tend to prefer $\mathrm{NH}_{4}^{+}$as their main $\mathrm{N}$ source. They can tolerate high $\mathrm{NH}_{4}^{+}$concentrations and often possess a reduced capacity to utilise $\mathrm{NO}_{3}^{-}$(Forde and Clarkson, 1999; Britto and Kronzucker, 2002; Schjoerring et al., 2002). A lack of nitrate reductase synthesis may be one physiological explanation for poor $\mathrm{NO}_{3}^{-}$utilisation (Koyama and Tokuchi, 2003).

In contrast, species of less acidic or calcareous, open and disturbed soils (e.g. after fire (Cruz et al., 2008)), which tend to have faster nitrification rates (e.g. fast growing annuals including agricultural crops and pioneer trees), generally prefer $\mathrm{NO}_{3}^{-}$or a mixture of both $\mathrm{NH}_{4}^{+}$and $\mathrm{NO}_{3}^{-}$(e.g. Pearson and Stewart, 1993; FalkengrenGrerup, 1995; Pearson and Soares, 1995).

As an illustration we use data detailing the presence or absence of 98 plant species in 520 vegetation relevés in which soil $\mathrm{NH}_{4}^{+}: \mathrm{NO}_{3}^{-}$ ratio was also measured to determine the relationship between species abundance and soil $\mathrm{NH}_{4}^{+}: \mathrm{NO}_{3}^{-}$ratio (see Wamelink et al. (2005) for details of survey methods). Species associated with high $\mathrm{NH}_{4}^{+}: \mathrm{NO}_{3}^{-}$ratios or independent in their response include some trees (e.g. Quercus robur), (dwarf) shrubs and generalist species like Molinia caerulea (Fig. 4a and b). Species associated with low $\mathrm{NH}_{4}^{+}: \mathrm{NO}_{3}^{-}$ratios include many species of (wet) grasslands, like 
Ranunculus repens (Fig. 4c). Other variables such as soil moisture have not been taken into account in these analyses so co-variation cannot be ruled out.

Although plants may have clear preferences in terms of $\mathrm{N}$ form, uptake rates do not necessarily reflect this. In the presence of both inorganic $\mathrm{N}$ forms, $\mathrm{NH}_{4}^{+}$is more readily taken up by most plants, because its reduced state makes its uptake less energetically costly
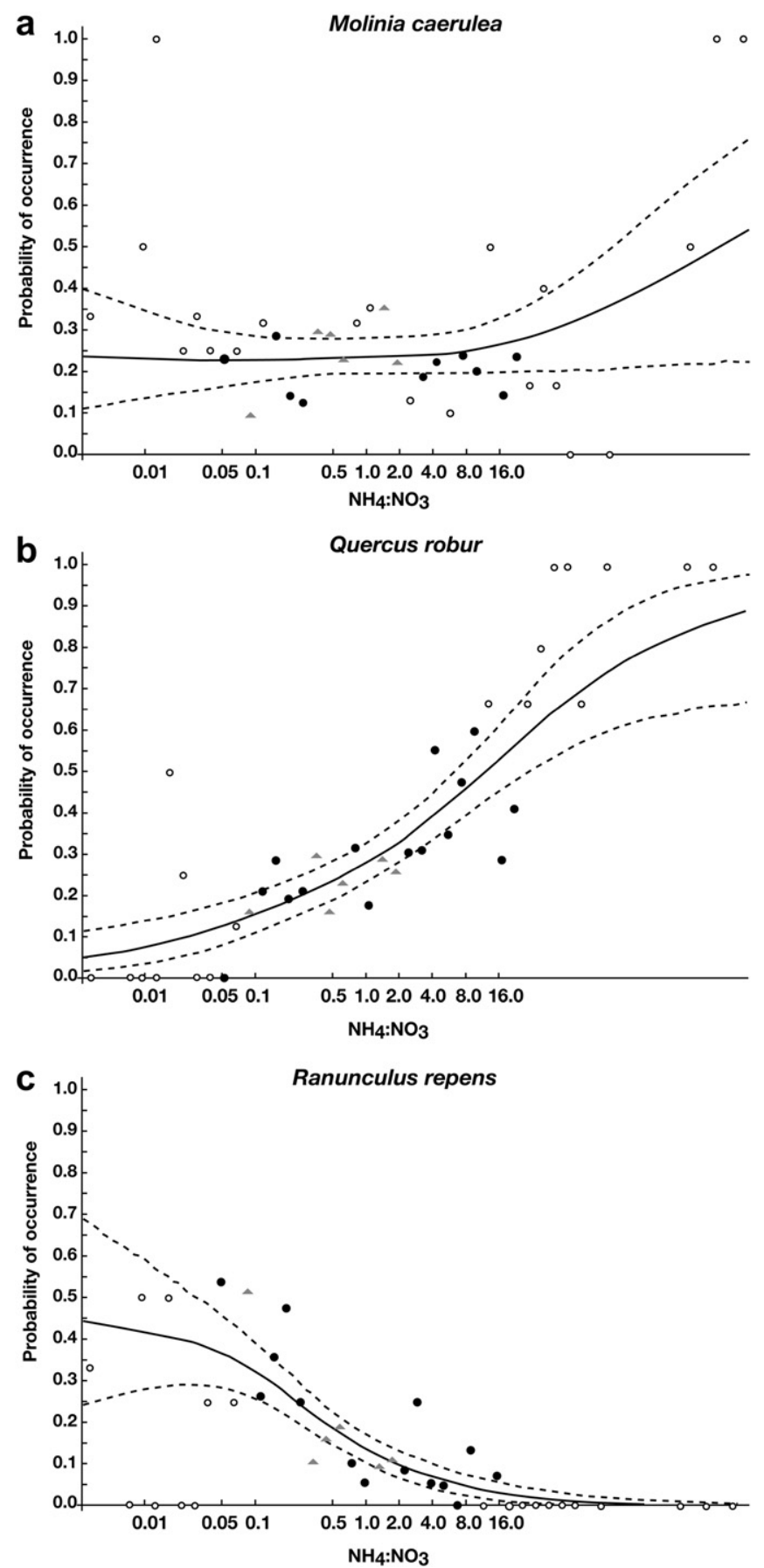

Fig. 4. Response curves and $95 \%$ confidence intervals (broken lines) of three plant species across a $\mathrm{NH}_{4}^{+}: \mathrm{NO}_{3}^{-}$ratio gradient. The curves represent species with (a) a positive association with high $\mathrm{NH}_{4}^{+}: \mathrm{NO}_{3}^{-}$ratios, (b) abundance independent of $\mathrm{NH}_{4}^{+}: \mathrm{NO}_{3}^{-}$ratio, and (c) a species associated with low $\mathrm{NH}_{4}^{+}: \mathrm{NO}_{3}^{-}$ratios. Open circles are those in which the probability of occurrence is calculated from $\leq 10$ relevés, filled circles were drawn from 11 to 25 relevés and triangles $26-50$ relevés. See Wamelink et al. (2005) for methods, soils were collected in the field, extracted using $0.01 \mathrm{M} \mathrm{CaCl}_{2}$ solution and analysed using an autoanalyser. than that of $\mathrm{NO}_{3}^{-}$(Bloom et al., 1992). Even in plants that can suffer from $\mathrm{NH}_{4}^{+}$toxicity, $\mathrm{NH}_{4}^{+}$uptake often exceeds that of $\mathrm{NO}_{3}^{-}$(De Graaf et al., 1998).

The form of $\mathrm{N}$ taken up or experienced by a plant may affect its health and performance. There is considerable evidence that sole $\mathrm{NH}_{4}^{+}-\mathrm{N}$ nutrition and high $\mathrm{NH}_{4}^{+}: \mathrm{NO}_{3}^{-}$ratios are toxic to plants (e.g. Dijk and Eck, 1995; De Graaf et al., 1998; Van den Berg et al., 2005). $\mathrm{NH}_{4}^{+}$toxicity is manifested by leaf chlorosis, stunted root growth, increased shoot: root ratio, decreased fine: coarse root ratio, growth retardation and, in extreme cases, plant death (Britto and Kronzucker, 2002; Van den Berg et al., 2005; Boxman et al., 1991). Several non-exclusive mechanisms have been postulated as the cause of this toxicity. These are (1) $\mathrm{NH}_{4}^{+}$uptake reduces the uptake of important cations such as $\mathrm{Ca}^{2+}, \mathrm{Mg}^{2+}$ and $\mathrm{K}^{+}$(Marschner, 1995); (2) $\mathrm{NH}_{4}^{+}$is metabolised immediately to $\mathrm{N}$-rich amides and amino acids within plant cells (Raven and Smith, 1976), diverting resources away from plant growth (Schortemeyer et al., 1997); (3) $\mathrm{NH}_{4}^{+}$uptake and assimilation imposes homeostatic energetic costs on the plant to maintain cytosol $\mathrm{pH}$, potentially retarding growth (Bligny et al., 1997; Gerendas and Ratcliffe, 2000).

\subsection{Variation in plant tolerance to $\mathrm{NH}_{x}$}

Regardless of the mechanism by which $\mathrm{NH}_{\mathrm{X}}$ impairs plant performance, it is clear that plant species differ strongly in their tolerance of high $\mathrm{NH}_{\mathrm{x}}$ concentrations. For species of originally weakly acid soils $(4.5<\mathrm{pH}<6.5) \mathrm{NH}_{4}^{+}$toxicity occurs at external concentrations of $100 \mu \mathrm{mol} \mathrm{l}^{-1}$ or less (Dijk and Eck, 1995; De Graaf et al., 1998; Van den Berg et al., 2005), but in species from acid soils it is only manifested at much higher concentrations (Boxman et al., 1991; De Graaf et al., 1998). Underlying these patterns are physiological differences between species. Many plants, including bryophytes, respond to $\mathrm{NH}_{4}^{+}$uptake by synthesising specific amino acids and amides, particularly amino acids with a low C:N ratio (e.g. Lucassen et al., 2003; Limpens and Berendse, 2003), and this may help to prevent $\mathrm{NH}_{4}^{+}$toxicity. Bryophyte and herb species have shown increases in the fraction of $\mathrm{N}$-rich free amino acids when grown at increased $\mathrm{N}$ supply, with $\mathrm{NH}_{4}^{+}$as the dominant $\mathrm{N}$ form, in both greenhouse and field experiments (Fig. 5).

Differences in the sensitivity of plant species to reductions in their cytoplasmic $\mathrm{pH}$ (acidosis) and in the capacity of species to buffer their cytoplasm, may also explain species-specific responses to $\mathrm{NH}_{\mathrm{X}}$ deposition (Pearson and Stewart, 1993). For appropriate cell functioning, the $\mathrm{pH}$ of the cytosol should be maintained within an appropriate range. Plants which predominantly take up and assimilate $\mathrm{NO}_{3}^{-}$generate bases and thereby buffering capacity, either through $\mathrm{OH}^{-}$release or by base cation uptake. This reduces their sensitivity to cytoplasmic acidosis. In contrast, with $\mathrm{NH}_{\mathrm{X}}$ uptake plants generate acidity instead of $\mathrm{OH}^{-}$. Though it has been shown that $\mathrm{NH}_{4}^{+}$nutrition does not always lead to decreased cytosol pH (Bligny et al. 1997; Gerendas and Ratcliffe, 2000), maintaining optimal cytosol $\mathrm{pH}$ is an energy demanding process. This energy is not available for plant maintenance or growth and may therefore, at least partly explain the retarded growth of many species grown on $\mathrm{NH}_{4}^{+}$nutrition (Britto and Kronzucker, 2002).

Light may also play a role in modifying species responses to $\mathrm{NH}_{\mathrm{X}}$ as its toxicity is less pronounced at low-light intensity (Britto and Kronzucker, 2002). This may mean that understory species are less likely to be sensitive to increases in the ratio of $\mathrm{NH}_{\mathrm{x}}: \mathrm{NO}_{\mathrm{y}}$ inputs but more research is needed to test this. Plants susceptible to $\mathrm{NH}_{4}^{+}$ toxicity might be afflicted by reduced rates of net photosynthesis, and thus, are in lower need of N. However, understory plants are most likely well adapted to these low-light conditions, with 'normal' photosynthesis rates in shaded conditions. 


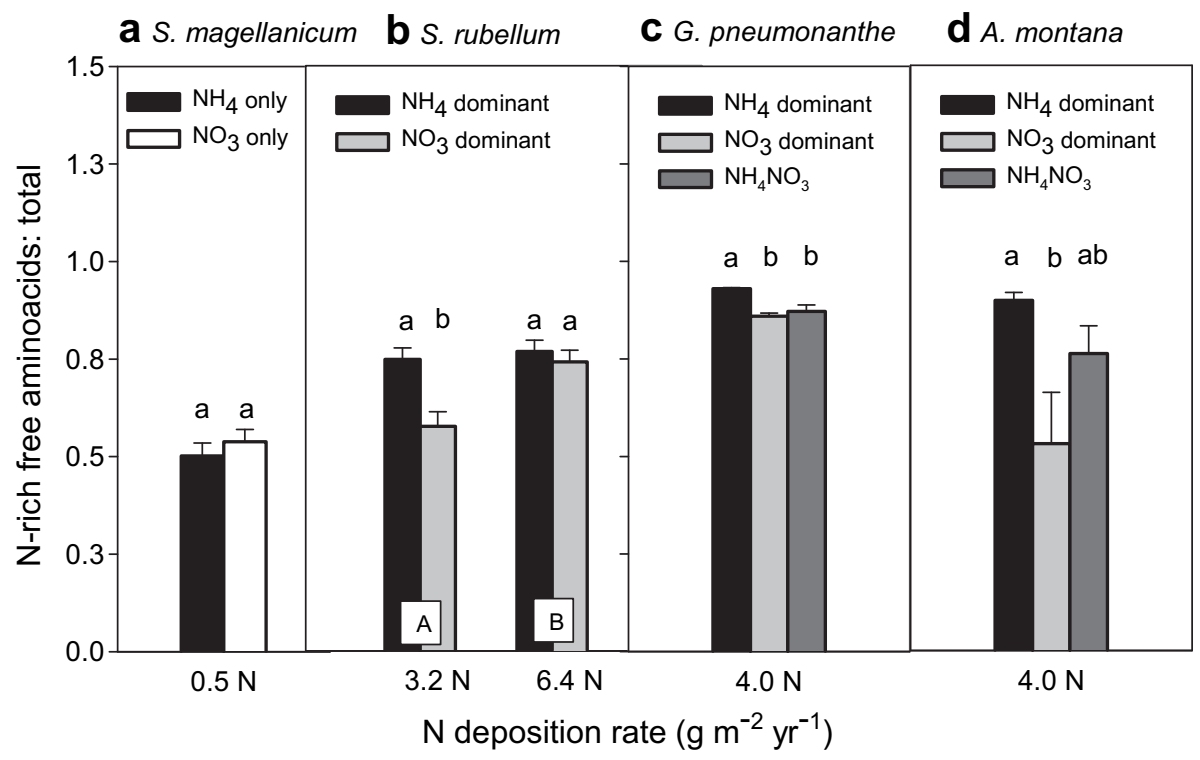

Fig. 5. The ratio between the concentrations of the three main $\mathrm{N}$-rich free amino acids (arginine, glutamine and asparagine) and all free amino acids ( $g \mathrm{~g}^{-1}$ ) in bryophytes from $\mathrm{N}$ poor acidic ecosystems ((a) Sphagnum magellanicum, (b) Sphagnum rubellum) and in two perennial herbs from N-poor, weakly buffered ecosystems ((c) Gentiana pneumonanthe, (d) Arnica montana) subjected to different $\mathrm{NH}_{4}^{+}: \mathrm{NO}_{3}^{-}$ratios and $\mathrm{N}$ supply. Reduced or oxidised $\mathrm{N}$ treatments were applied to the bryophytes and plants in the greenhouse for three months (a), in the field for three years at $\mathrm{NH}_{\mathrm{x}}: \mathrm{NO}_{\mathrm{y}}$ ratios of 1:9 and 9:1 (b) or in a climate chamber for three months at $\mathrm{NH}_{\mathrm{x}}: \mathrm{NO}_{\mathrm{y}}$ ratios of 4:1,1:1 and 1:4 (c, d). Different capital letters indicate significant effects of $\mathrm{N}$ load (ANOVA, $p<0.05$ ), different lower case letters indicate effects of $\mathrm{N}$ form (paired $t$-test). Data sources: (a) J. Limpens (unpublished) and (b-d) L.J.L. van den Berg (unpublished)

In addition to these effects on mature plants $\mathrm{NH}_{\mathrm{x}}: \mathrm{NO}_{\mathrm{y}}$ ratio may also influence germination and early seedling establishment. Both $\mathrm{N}$ forms are known to break seed dormancy but germination effects will be species specific as not all species are stimulated, some only respond to $\mathrm{NO}_{3}^{-}$or $\mathrm{NH}_{4}^{+}$, and responses may be both positive and negative (e.g. Singh and Amritphale, 1992; Dorland et al., 2003; Luna and Moreno, 2009).

Plant species sensitivity to $\mathrm{NH}_{\mathrm{x}}: \mathrm{NO}_{\mathrm{y}}$ ratio may also depend upon the preferences and sensitivities of their associated symbionts. A meta-analysis of $\mathrm{N}$ addition effects on mycorrhizal fungi found negative effects of $\mathrm{N}$ addition but no significant impact of $\mathrm{N}$ form (Treseder, 2004). However, some individual studies have found an impact of $\mathrm{N}$ form, for example, Yoshida and Allen, 2001 found a large mycorrhizal response to ammonium addition but not nitrate addition in costal sage scrub species in California. Ectomyorrhizal plants appear to prefer $\mathrm{NH}_{4}^{+}$(e.g. Cumming, 1990), whereas arbuscular mycorrhizal (AM) plants seem to prefer $\mathrm{NO}_{3}^{-}$(e.g. Cuenca and Azcon, 1994; Persson et al., 2003) although this is not always the case (e.g. Yoshida and Allen, 2001). These preferences are consistent with the natural patterns of $\mathrm{N}$ availability and plant uptake, and mycorrhizal distribution (Nordin et al., 2001). This implies that AM plant species may decline when the $\mathrm{NH}_{\mathrm{y}}: \mathrm{NO}_{\mathrm{x}}$ ratio in the soil is high or increasing.

\section{Community and ecosystem responses to changing $\mathrm{NH}_{\mathrm{x}}: \mathrm{NO}_{\mathrm{y}}$}

Despite strong evidence that $\mathrm{NH}_{\mathrm{x}}: \mathrm{NO}_{\mathrm{y}}$ ratio affects plant species differentially with respect to germination, growth and survival it is still not known how important the form of $\mathrm{N}$ is relative to the amount of $\mathrm{N}$ being deposited in determining community responses to $\mathrm{N}$ enrichment. Where ratio effects are important the mechanism is likely to differ depending on soil $\mathrm{NH}_{4}^{+}$and $\mathrm{NO}_{3}^{-}$concentrations as determined by the factors and processes explained above, and by their differential effects (toxicity, growth etc) on species performance.
Based on the preceding review we hypothesize that there is a gradient of $\mathrm{NH}_{4}^{+}: \mathrm{NO}_{3}^{-}$ratios in the soil, driven primarily by soil $\mathrm{pH}$ and subsequently nitrification rates, with plant species life history strategies evolving to specialise at different points on this gradient and thus displaying a range of inherent sensitivities to $\mathrm{NH}_{4}^{+}$(Fig. 6). We also predict that the relationship between $\mathrm{NH}_{4}^{+}: \mathrm{NO}_{3}^{-}$ratios in the soil and plant species is general, with these patterns being found in a wide range of habitats. Such a natural gradient generates context dependency in the effects of $\mathrm{NH}_{\mathrm{x}}$ and $\mathrm{NO}_{\mathrm{y}}$ deposits and makes the prediction of responses to changing $\mathrm{NH}_{\mathrm{x}}: \mathrm{NO}_{\mathrm{y}}$ input ratios challenging.

In acid environments $(\mathrm{pH}<4.5)$ where nitrification rates are frequently low, $\mathrm{N}$ will accumulate as $\mathrm{NH}_{4}^{+}$, potentially reaching toxic concentrations. In such cases species differences in sensitivity to high $\mathrm{NH}_{4}^{+}$concentration will determine community response (Fig. 6).

Acidification processes related to high $\mathrm{NH}_{4}^{+}$concentrations result in the mobilisation of metals and an increase in metal concentrations such as aluminium $\left(\mathrm{Al}^{3+}\right)$ and iron $\left(\mathrm{Fe}^{3+}\right)$ (Stevens et al., 2009). In addition base cation $\left(\mathrm{Ca}^{2+}, \mathrm{Mg}^{2+}\right)$ concentrations decline. Tolerance to free metal concentrations may also be important in determining community response (e.g. De Graaf et al., 1994). While some species found at these sites may tolerate these increases in $\mathrm{NH}_{4}^{+}$and metal ion concentrations, species growth rates and thresholds for tolerance may differ within a community (Kleijn et al., 2008). For any given community it is likely to be those species with the lowest tolerance to $\mathrm{NH}_{4}^{+}$and metals and strongest preference for $\mathrm{NO}_{3}^{-}$that will decline when the ratio of $\mathrm{NH}_{\mathrm{x}}: \mathrm{NO}_{\mathrm{y}}$ inputs increases. Evidence for this has been found in dry heaths $(\mathrm{pH} 3.8-4.9)$, where soil $\mathrm{NH}_{4}^{+}$ concentrations were strongly negatively correlated with the number of plant species and a better predictor for plant diversity in this ecosystem than $\mathrm{pH}$ or $\mathrm{Al}^{3+}$ (De Graaf et al., 2009).

As the initial soil $\mathrm{pH}$ increases and nitrification rates increase a greater proportion of $\mathrm{NH}_{\mathrm{x}}$ deposition inputs will be converted into the non-toxic $\mathrm{NO}_{3}^{-}$form. We predict that in soil of intermediate $\mathrm{pH}(4.5-6.0)$ nitrification rates will be sufficient to convert a large 


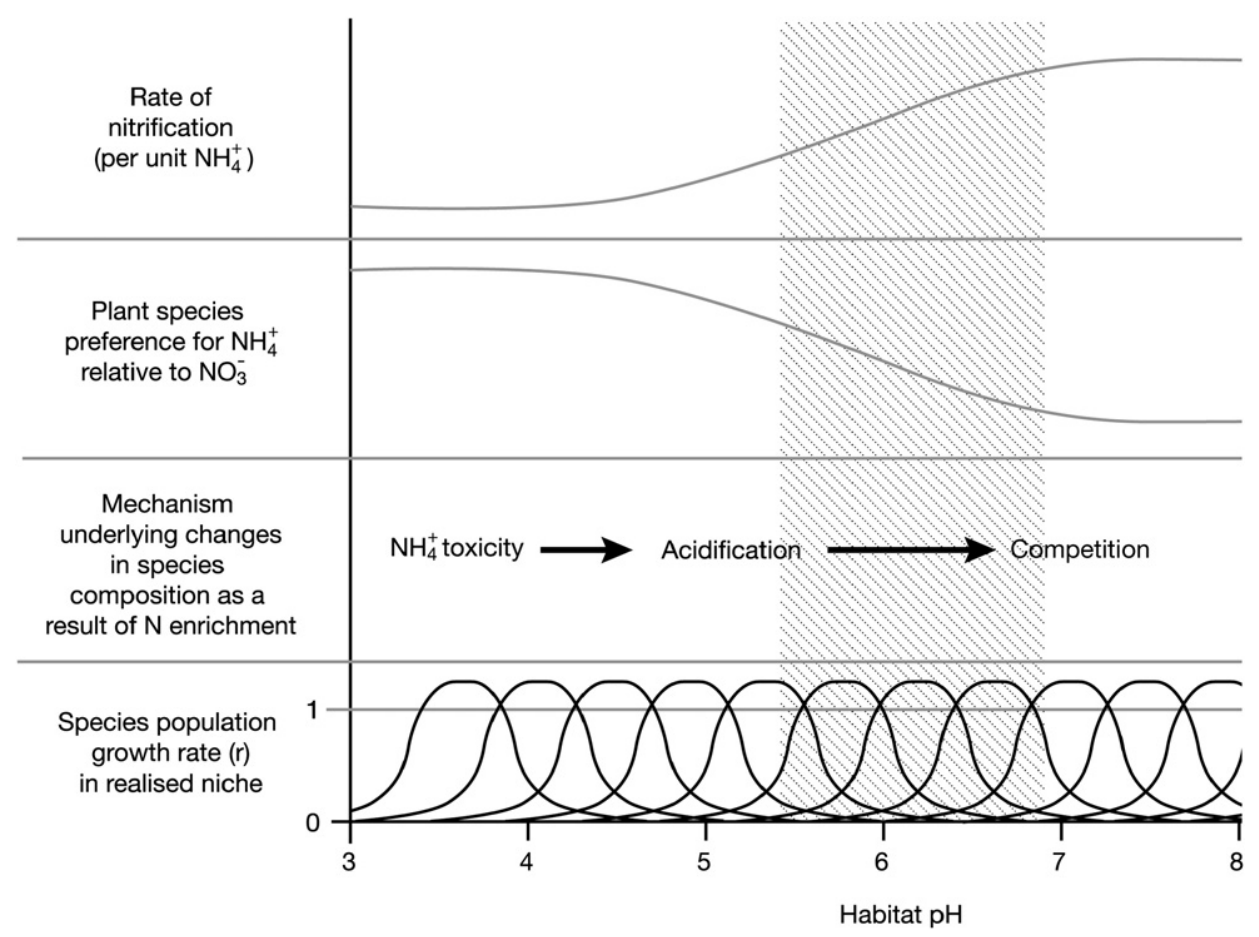

Fig. 6. Hypothetical relationships between the background soil pH and the mechanisms regulating plant community composition responses to $\mathrm{N}$ addition. The performance of different species, as represented by $\mathrm{r}$, with each hump equivalent to a species' realised niche, differs across the pH gradient and so any shift in conditions results in compositional change. In low pH systems high $\mathrm{NH}_{\mathrm{x}}: \mathrm{NO}_{\mathrm{y}}$ inputs move the community to the left and low $\mathrm{NH}_{\mathrm{x}}: \mathrm{NO}_{\mathrm{y}}$ inputs shift the community to the right. At higher pH (probably $\sim 5.5$ ) most $\mathrm{NH}_{4}^{+}$ is nitrified and the form of $\mathrm{N}$ addition becomes less important in predicting plant community response. The hatched area represents the region of uncertainty in which high nitrification rates and buffering capacity render the form of $\mathrm{N}$ inputs unimportant.

proportion of the deposited $\mathrm{NH}_{\mathrm{x}}$ into $\mathrm{NO}_{\mathrm{y}}$. However, if associated $\mathrm{pH}$ decline is large, and soil $\mathrm{pH}$ approaches 4.5 , then deposition of $\mathrm{NH}_{\mathrm{x}}$ may cause species loss via $\mathrm{Al}^{3+}$ or $\mathrm{H}^{+}$toxicity, and shift conditions towards low pH conditions in which $\mathrm{NH}_{4}^{+}$accumulates (Fig. 6). Species that are adapted to very acid conditions will not suffer from $\mathrm{NH}_{4}^{+}$toxicity. For them, the enhanced $\mathrm{N}$-availability will lead to increased productivity and enhanced competitive ability. In wet heathlands this has resulted in vegetation changes from dwarf shrub dominated heaths to domination of grasses such as M. caerulea and Deschampsia flexuosa. We therefore hypothesize that in soil of intermediate $\mathrm{pH}$ species typically found on soils with pH 4.5-6 will decrease in abundance with increasing $\mathrm{NH}_{\mathrm{x}}: \mathrm{NO}_{\mathrm{y}}$ inputs and that species typical of soils of $\mathrm{pH}<4.5$, or insensitive species e.g. M. caerulea, will increase in abundance. In heathlands and grasslands on weakly buffered soils, it has been shown that soil acidification was the main factor in explaining plant species richness declines, thereby supporting the current hypothesis (De Graaf et al. 2009). In summary, we predict that in soils of low and intermediate $\mathrm{pH}$ the species with the highest $\mathrm{pH}$ and lowest $\mathrm{NH}_{4}^{+}: \mathrm{NO}_{3}^{-}$ optima are most at risk if the system experiences an increase in $\mathrm{NH}_{\mathrm{x}}: \mathrm{NO}_{\mathrm{y}}$ input ratios.

In more neutral soils ( $\mathrm{pH}$ 6.0-7.5) an increase in the $\mathrm{NH}_{\mathrm{x}}: \mathrm{NO}_{\mathrm{y}}$ ratio of inputs will be mitigated by rapid nitrification of $\mathrm{NH}_{4}^{+}$to $\mathrm{NO}_{3}^{-}$, thereby preventing ammonium toxicity from occurring. The high initial soil $\mathrm{pH}$ will also mean that the soils are initially well buffered against the effects of acidification. In these soils with a high $\mathrm{NH}_{4}^{+}$turnover, $\mathrm{N}$ deposition is more likely to have a fertilising effect and it may be the degree of $\mathrm{N}$ limitation and the total amount of $\mathrm{N}$ deposited, rather than its form that is important to plant community dynamics. In such cases community response to $\mathrm{N}$ is most likely driven by increases in plant productivity (Clark et al., 2007), with tall, rapidly growing and canopy forming species casting a shade which excludes smaller plants (Bobbink, 1991;
Manning et al., 2009; Hautier et al., 2009) and legumes, which lose their $\mathrm{N}$ fixing advantage and are outcompeted at high $\mathrm{N}$ availability (Suding et al., 2005).

Further research is required to confirm the relationship we suggest between soil $\mathrm{NH}_{4}^{+}: \mathrm{NO}_{3}^{-}$ratios and plant species composition. A number of modifying factors need to be assessed including the habitat specific threshold of soil conditions above which high nitrification rate renders the form of $\mathrm{N}$ inputs unimportant, and the degree of generality in the relationship between $\mathrm{pH}$ and nitrification rates should be evaluated. The potential for acidification is also likely to vary between sites depending on their soil buffering system. We therefore need to identify the positions on natural environmental gradients above which plant community responses to $\mathrm{N}$ addition are no longer predominantly determined by $\mathrm{NH}_{\mathrm{y}}$ sensitivity mechanisms, but by acidification and light or other nutrient competition. Although this hypothesis is community dependent in its details, and there are likely to be exceptions to the hypothesized trends, its principles are general and so it could be tested with a combination of experimental and survey work across a range of systems, adopting an approach similar to that of Kleijn et al. (2008).

\section{Assessment and management of the ecosystem impacts of changing $\mathrm{NH}_{\mathrm{x}}: \mathrm{NO}_{\mathrm{y}}$ ratios}

While the synthesis presented here suggests an important role of $\mathrm{N}$ form in determining ecosystem responses to $\mathrm{N}$ deposition there is great difficulty in assessing these effects. One such hurdle is that the largest values of $\mathrm{N}$ deposition are always dominated by gaseous $\mathrm{NH}_{\mathrm{x}}$ deposition. As a result it is difficult to distinguish the effects of high $\mathrm{NH}_{\mathrm{x}}: \mathrm{NO}_{\mathrm{y}}$ ratio and high total $\mathrm{N}$ load. The observational data of Stevens et al. (2004) and Kleijn et al. (2008) for instance, show correlations (Pearson's $r$ ) of 0.42 and $0.35(p<0.001,0.07)$ between 
total $\mathrm{N}$ load and $\mathrm{NH}_{\mathrm{x}}: \mathrm{NO}_{\mathrm{y}}$ ratio respectively (data taken from species level means from Table 1 of Kleijn et al. 2008). The correlation between $\mathrm{NH}_{4}^{+}$deposition and total $\mathrm{N}$ deposition is high $(r=0.98$ and 1.00; $p<0.001$ in both cases), making it difficult to distinguish whether fertilization, acidification or $\mathrm{NH}_{4}^{+}$toxicity, or a combination of these mechanisms, may be responsible for compositional change of ecosystems. Their relative importance can only be found by acquiring data from ecosystems in which the $\mathrm{NH}_{4}^{+} \mathrm{N}$ deposition load and $\mathrm{NH}_{\mathrm{x}}: \mathrm{NO}_{\mathrm{y}}$ ratio correlations are absent, in combination with experimental work which removes this correlation (e.g. Van den Berg et al., 2008). Experimental work in mesocosms or in low $\mathrm{N}$ input regions may overcome this problem but measurements must distinguish between the acidifying and toxic effects of $\mathrm{NH}_{4}^{+}$. Here, plant community data may be combined with physiological measures of plant health, e.g. amino acid concentrations, pigment content and chlorophyll fluorescence, that may indicate which stresses are the causes of species loss.

Using conservation management to mitigate $\mathrm{N}$ deposition impacts is challenging. Many of the available techniques for removing $\mathrm{N}$ also involve the removal of carbon and other nutrients, thus potentially altering a range of ecosystem functions. As a result the only truly effective way of managing for $\mathrm{N}$ deposition is the reduction of $\mathrm{N}$ inputs to the ecosystem by the reduction of $\mathrm{N}$ emissions. Critical loads for $\mathrm{N}$ deposition are currently based on total reactive $\mathrm{N}$ deposition but devising habitat specific critical loads for the components of deposition and $\mathrm{NH}_{\mathrm{x}}: \mathrm{NO}_{\mathrm{y}}$ ratio could be beneficial in some ecosystems. This still leaves the problem of potentially high amounts of $\mathrm{NH}_{4}^{+}$accumulated in the soil and slow recovery. Suggestions for deposition management on a local scale have been made, such as the use of tree shelter belts to capture $\mathrm{NH}_{3}$ (Theobald et al., 2001), but generally, the reduction of $\mathrm{N}$ deposition requires action at a national or international level. Unfortunately, the formulation and delivery of policy at these levels is a slow process and more immediate action is often required if sites of conservation importance are to be protected and restored. An understanding of the mechanisms underlying ecosystem responses to different ratios $\mathrm{N}$ input should allow for the development of management and mitigation options.

The most appropriate form of management to apply in a habitat will depend on the vegetation community and its position along the $\mathrm{pH}$ gradient described above and in Fig. 6 . In low $\mathrm{pH}$ soils (to the left of Fig. 6), where $\mathrm{NH}_{4}^{+}$and heavy metal toxicity are likely to be the key processes associated with changes in species composition caused by $\mathrm{N}$ enrichment, management must change soil properties to restore low $\mathrm{NH}_{\mathrm{x}}$ concentration and reduce the $\mathrm{NH}_{\mathrm{x}}$ : $\mathrm{NO}_{\mathrm{y}}$ ratio (Kleijn et al., 2008). One of the most effective ways to do this is by turf cutting and liming. Turf (or sod) cutting removes excess nutrients and restores damaged ecosystems. It has been used successfully in a range of habitats (e.g. heathland: Dorland et al., 2005a; De Graaf et al. 1998; grassland: Jansen and Roelofs, 1996; fens: Beltman et al., 2001; pine forest: Boxman and Roelofs, 2006), especially in the Netherlands. It may, however, decrease the nitrification potential of acidified soils and lead to a rapid increase in soil $\mathrm{NH}_{4}^{+}$concentrations (Dorland et al., 2003). The addition of lime after cutting has been found to successfully prevent $\mathrm{NH}_{4}^{+}$accumulation by increasing nitrification (Dorland et al., 2004; De Graaf et al., 1998; Van den Berg et al., 2003). While a powerful tool, turf cutting is a dramatic and expensive form of management with a number of potential problems (see Klap and Schmidt, 1995; Van den Berg et al., 2003;Dorland et al., 2004; Vergeer et al., 2006).

An alternative and emerging option for removing reactive $\mathrm{N}$ from soils is the addition of carbon (C). The addition of organic $C$ to the soil increases the $\mathrm{C}: \mathrm{N}$ ratio and could be expected to induce microbial communities to immobilize N. Several studies have reported successful reduction of soil $\mathrm{N}$ availability and a reduction in nitrophillous species as a result of addition of C supplements (e.g. Török et al., 2000; Eschen et al., 2007). While there are a limited number of $C$ addition studies on soils that are likely to have naturally low nitrification rates, results to date suggest that carbon addition may be more effective in reducing soil $\mathrm{NO}_{3}^{-}$concentrations than those of $\mathrm{NH}_{4}^{+}$(Török et al., 2000; Blumenthal et al., 2003; Prober et al., 2005; Eschen et al., 2007). It may therefore be more suitable for systems with naturally high nitrification rates (the right of Fig. 6).

At slightly higher $\mathrm{pH}$, moving towards the centre of Fig. 6, where acidification rather than the toxicity is the main driver of compositional changes resulting from $\mathrm{N}$ enrichment, liming is an effective management option. Liming has been widely used in many terrestrial habitats to counteract acidification from atmospheric pollutants (e.g. forests: Löfgren et al., 2009; heathland: Dorland et al. 2005b; grassland: Blake et al., 1999; bogs: Sanger et al., 1993). Increasing the $\mathrm{pH}$ also has the potential to increase nitrification, thus reducing the $\mathrm{NH}_{\mathrm{x}}: \mathrm{NO}_{\mathrm{y}}$ ratio. In areas fed by base-rich groundwater restoration of hydrology by blocking drainage ditches has been used as an alternative method to reduce acidification in combination with sod cutting (Roelofs et al., 1987). Increasing the $\mathrm{pH}$ has the potential to increase nitrification reducing the $\mathrm{NH}_{\mathrm{x}}: \mathrm{NO}_{\mathrm{y}}$ ratio.

In high $\mathrm{pH}$ and nitrification rate systems, where most species have a preference for $\mathrm{NO}_{3}^{-}$(i.e. those found at the far right of Fig. 6) canopy closure and light limitation are likely to be the most important mechanisms driving species changes as a result of $\mathrm{N}$ deposition. Here measures can be taken to reduce competition for light. This could include an increase in cutting frequency or grazing intensity, especially in ecosystems dominated by herbaceous vegetation (e.g. Bobbink and Willems, 1988). Nutrient levels can also be reduced when these methods are combined with the removal of cut vegetation or the folding of livestock (Ausden, 2007). This method is commonly used in the restoration of grasslands on former agricultural land (e.g. Walker et al., 2003) and can change species composition, reducing the cover of productive grasses promoted by $\mathrm{N}$ enrichment.

\section{Conclusion}

Future changes in the ratio of $\mathrm{NH}_{\mathrm{y}}$ and $\mathrm{NO}_{\mathrm{x}}$ inputs have the potential to alter numerous soil processes, plant $\mathrm{N}$ uptake, community composition and ecosystem functioning. This has important implications for plant community composition as, depending on soil type and habitat, some species may be favoured by the changing ratio to the expense of others. Further research is needed to test the hypothesis that there is a natural spectrum of $\mathrm{NH}_{\mathrm{x}}: \mathrm{NO}_{\mathrm{y}}$ ratios in the soil, driven primarily by soil $\mathrm{pH}$ and buffer capacity and subsequently nitrification rates. The response of plants to $\mathrm{NH}_{\mathrm{x}}: \mathrm{NO}_{\mathrm{y}}$ ratios at different points on this gradient also needs to be investigated, as does its generality to a wide range of ecosystems as it is in many poorly studies regions of the world, e.g. South America, East Africa and East Asia where $\mathrm{NH}_{\mathrm{x}}: \mathrm{NO}_{\mathrm{y}}$ ratios are expected to show the greatest increases. If this hypothesis is supported, and found to be general across a range of ecosystems it may enable us to predict ecosystem responses to changing $\mathrm{NH}_{\mathrm{x}}: \mathrm{NO}_{\mathrm{y}}$ ratios, increasing the effectiveness of the management and mitigation of $\mathrm{N}$ deposition impacts.

\section{Acknowledgements}

We are grateful to the British Council and the Netherlands Organization for scientific research for funding the workshop at which this review was initiated. Dina Koulama and Rodolphe Bernard assisted with figure preparation. 


\section{References}

Asman, W.A.H., Sutton, M.A., Schjoerring, J.K., 1998. Ammonia: emission, atmospheric transport and deposition. New Phytologist 139, 27-48.

Ausden, M., 2007. Habitat Management for Conservation: A Handbook of Techniques. Oxford University Press, Oxford.

Beltman, B., Van den Broek, T., Barendregt, A., Bootsma, M.C., Grootjans, A.P., 2001. Rehabilitation of acidified and eutrophied fens in the Netherlands: effects of hydrologic manipulation and liming. Ecological Engineering 17, 21-31.

Berg, B., Matzner, E., 1997. Effect of $\mathrm{N}$ deposition on decomposition of plant litte and soil organic matter in forest ecosystems. Environmental Reviews 5, 1-25.

Berger, T.W., Untersteiner, H., Schume, H., Jost, G., 2008. Throughfall fluxes in a secondary spruce (Picea abies), a beech (Fagus sylvatica) and a mixed sprucebeech stand. Forest Ecology and Management 255, 605-618.

Blake, L., Goulding, K.W.T., Mott, C.J.B., Johnston, A.E., 1999. Changes in soil chemistry accompanying acidification over more than 100 years under woodland and grass at Rothamsted Experimental Station, UK. European Journal of Soil Science 50, 401-412.

Bligny, R., Gout, E., Kaiser, W., Heber, U., Walker, D., Douce, R., 1997. pH regulation in acid-stressed leaves of pea plants grown in the presence of nitrate or ammonium salts: studies involving P-31-NMR spectroscopy and chlorophyll fluorescence. Biochimica et Biophysica Acta - Bioenergetics 1320, 142-152.

Bloom, A.J., Sukrapanna, S.S., Warner, R.L., 1992. Root respiration associated with ammonium and nitrate absorption and assimilation by barley. Plant Physiology 99, 1294-1301.

Blumenthal, D.M., Jordan, N.R., Russelle, M.P., 2003. Soil carbon addition controls weeds and facilitates prairie restoration. Ecological Applications 13, 605-615.

Bobbink, R., 1991. Effects of nutrient enrichment in Dutch chalk grassland. Journal o Applied Ecology 28, 28-41.

Bobbink, R., Hornung, M., Roelofs, J.G.M., 1998. The effects of air borne nitrogen pollutants on species diversity in natural and semi-natural European vegetation. Journal of Ecology 86, 717-738.

Bobbink, R., Ashmore, M., Braum, S., Fluckinger, W., Van den Wyngaert, I.J.J., 2003. Empirical nitrogen critical loads for natural and semi-natural ecosystems: 2002 update. In: Achermann, B., Bobbink, R. (Eds.), Empirical Critical Loads fo Nitrogen, Environmental Documentation No. 164 Air. Swiss Agency for Environment, Forest and Landscape SAEFL, Berne.

Bobbink, R., Hicks, K., Galloway, J., Spranger, T., Alkemade, R., Ashmore, M. Bustamante, M., Cinderby, S., Davidson, E., Dentener, F., Emmett, B. Erisman, J.W., Fenn, M., Gilliam, F., Nordin, A., Pardo, L., De Vries, W., 2010. Global assessment of nitrogen deposition effects on terrestrial plant diversity: a synthesis. Ecological Applications 20, 30-59.

Bobbink, R., Lamers, L.P.M., 2002. Effects of increased nitrogen deposition. In: Bell, J.N.B., Treshow, M. (Eds.), Air Pollution and Plant Life, second ed. John Wiley \& Sons, Ltd, Oxford, pp. 201-235.

Bobbink, R., Roelofs, J.G.M., 1995. Nitrogen critical loads for natural and seminatural ecosystems: the empirical approach. Water, Air and Soil Pollution 85, 2413-2418.

Bobbink, R., Willems, J.H., 1988. Effects of management and nutrient availability on vegetation structure of chalk grasslands. In: During, H.J., Wager, M.J.A., Willems, J.H. (Eds.), Diversity and Pattern in Plant Communities. Academic Publishing House, The Hague, pp. 183-193.

Booth, M.S., Stark, J.M., Rastetter, E., 2005. Controls on nitrogen cycling in terrestrial ecosystems: a synthetic analysis of literature data. Ecological Monographs 75 139-157.

Boxman, A.W., Krabbendam, H., Bellemakers, M.J.S., Roelofs, J.G.M., 1991. Effects of ammonium and aluminium on the development and nutrition of Pinus nigra in hydroculture. Environmental pollution 73, 119-136.

Boxman, A.W., Peters, C.H.J., Roelofs, J.G.M., 2008. Long term changes in atmospheric $\mathrm{N}$ and $\mathrm{S}$ throughfall deposition and effects on soil solution chemistry in a Scots pine forest in the Netherlands. Environmental Pollution 156, $1252-1259$.

Boxman, A.W., Roelofs, J.G.M., 2006. Effects of liming, sod-cutting and fertilization at ambient and decreased nitrogen deposition on the soil solution chemistry in a Scots pine forest in the Netherlands. Forest Ecology and Management 237, 237-245.

Britto, D.T., Kronzucker, H.J., 2002. $\mathrm{NH}_{4}^{\dagger}$ toxicity in higher plants: a critical review. Journal of Plant Physiology 159, 567-584.

Cape, J.N., van der Eerden, L.J., Sheppard, L.J., Leith, I.D., Sutton, M.A., 2009. Evidence for changing the critical level for ammonia. Environmental Pollution 157, 1033-1037.

Clark, C., Cleland, E.E., Collins, S.C., Fargione, J., Gough, L., Gross, K.L., Pennings, S. Suding, K.N., Grace, J., 2007. Environmental and plant community determinant of species loss following nitrogen enrichment. Ecology Letters 10, 596-607.

Cruz, C., Bio, A.M.F., Jullioti, A., Tavares, A., Dias, T., Martins-Loucao, M.A., 2008 Heterogeneity of soil surface ammonium concentration and other characteristics, related to plant specific variability in a Mediterranean-type ecosystem. Environmental Pollution 154, 414-423.

Cuenca, G., Azcon, R., 1994. Effects of ammonium and nitrate on the growth of vesicular-arbuscular mycorrhizal Eruthrina poeppigiana O.I. Cook seedlings. Biology and Fertility of Soils 18, 249-254.

Currey, P.M., Johnson, D., Sheppard, L.J., Leith, I.D., Toberman, H., van der Wal, R. Dawson, L.A., Artz, R.R.E., 2010. Turnover of labile and recalcitrant soil carbon differ in response to nitrate and ammonium deposition in an ombrotrophic peatland. Global Change Biology 16, 2307-2321.
Cumming, J.R., 1990. Nitrogen-source effects on Al-toxicity in nonmycorrhizal and mycorrhizal pitch pine (Pinus rigida) seedlings 2 . Nitrate reduction and $\mathrm{NO}_{3}$ uptake. Canadian Journal of Botany 68, 2653-2659.

De Graaf, M.C.C., Verbeek, P.J.M., Cals, P.J.M., Roelofs, J.G.M. 1994. Restoration of Acidified and Eutrophied Species Rich Heaths and Acidic Grasslands 1990-1994. Report to the Department of Ecology, University of Nijmegen, 248pp.

De Graaf, M.C.C., Verbeek, P.J.M., Bobbink, R., Roelofs, J.G.M., 1998. Restoration of species-rich dry heaths. The importance of appropriate soil conditions. Acta Botanica Neerlandica 47, 89-111.

De Graaf, M.C.C., Bobbink, R., Smits, N.A.C., Van Diggelen, R., Roelofs, J.G.M., 2009 Biodiversity, vegetation gradients and key biogeochemical processes in the heathland landscape. Biological Conservation 142, 2191-2201.

Dentener F.J., 2006. Global maps of atmospheric nitrogen deposition, 1860, 1993 and 2050. Data set. Oak Ridge National Laboratory Distributed Active Archive Center, Oak Ridge, Tennessee, U.S.A. doi:10.3334/ORNLDAAC/830. Available from: http://daac.ornl.gov.

DeForest, J.L., Zak, D.R., Pregitzer, K.S., Burton, A.J., 2004. Atmospheric nitrate deposition, microbial community composition, and enzyme activity in northern hardwood forests. Soil Science Society of America Journal 68, 132-138.

De Schrijver, A., Staelens, J., Wuyts, K., Van Hoydonck, G., Janssen, N., Mertens, J., Gielis, L., Geudens, G., Augusto, L., Verheyen, K., 2008. Effect of vegetation type on throughfall deposition and seepage flux. Environmental Pollution 153, 295-303.

De Klein, C.A.M., Van Logtestijn, R.S.P., 1996. Denitrification in grassland soils in the Netherlands in relation to irrigation, $\mathrm{N}$-application rate, soil water content and soil temperature. Soil Biology and Biochemistry 28, 231-237.

Dijk, E., Eck, N., 1995. Ammonium toxicity and nitrate response of axenically grown Dactylorhiza incarnata seedlings. New Phytologist 131, 361-367.

Dorland, E., Bobbink, R., Messelink, J.H., Verhoeven, J.T.A., 2003. Soil ammonium accumulation after sod cutting hampers the restoration of degraded wet heathlands. Journal of Applied Ecology 40, 804-814.

Dorland, E., van den Berg, L.J.L., van de Berg, A.J., Vermeer, M.L., Roelofs, J.G.M., Bobbink, R., 2004. The effects of sod cutting and additional liming on potential net nitrification in heathland soils. Plant and Soil 265, 267-277.

Dorland, E., Hart, M.A.C., Vermeer, M.L., Bobbink, R., 2005a. Assessing the success of wet heath restoration by combined sod cutting and liming. Applied Vegetation Science 8, 209-218.

Dorland, E., van den Berg, L.J.L., Brouwer, E., Roelofs, J.G.M., Bobbink, R., 2005b. Catchment liming to restore degraded, acidified heathlands and moorland pools. Restoration Ecology 13, 302-311.

Dupré, C., Stevens, C.J., Ranke, T., Bleeker, A., Peppler-Lisbach, C., Gowing, D.J.G., Dise, N.B., Dorland, E., Bobbink, R., Diekmann, M., 2010. Changes in species richness and composition in European acidic grasslands over the past 70 years: the contribution of cumulative atmospheric nitrogen deposition. Global Change Biology 16, 344-357.

Eschen, R., Mortimer, S.M., Lawson, C.S., Edwards, A.R., Brook, A.J., Igual, J.M. Hedlund, K., Schaffner, U., 2007. Carbon addition alters vegetation composition on ex-arable fields. Journal of Applied Ecology 44, 95-104.

Fagerli, H., Aas, W., 2008. Trends of nitrogen in air and precipitation: model results and observations at EMEP sites in Europe, 1980-2003. Environmental Pollution $154,448-461$.

Fangmeier, A., Hadwiger-Fangmeier, A., Van der Eerden, L., Jager, H.J., 1994. Effects of atmospheric ammonia on vegetation: a review. Environmental Pollution 86 43-82.

Falkengren-Grerup, U., 1995. Interspecies differences in the preference of ammonium and nitrate in vascular plants. Oecologia 102, 305-311.

Fenn, M.E., Baron, J.S., Allen, E.B., Rueth, H.M., Nydick, K.R., Geiser, L., Bowman, W.D. Sickman, J.O., Meixner, T., Johnson, D.W., Neitlich, P., 2003. Ecological effects of nitrogen deposition in the Western United States. BioScience 53, 404-420.

Forde, B.G., Clarkson, D.T., 1999. $\mathrm{NO}_{3}^{-}$and $\mathrm{NH}_{4}^{+}$nutrition of plants: physiological and molecular perspectives. Advances in Botanical Research 30, 1-90.

Fowler, D., O'Donoghue, M., Muller, J.B.A., Smith, R.I., Dragosits, U., Skiba, U. Sutton, M.A., Brimblecombe, P., 2004. A chronology of nitrogen deposition in the UK between 1900 and 2000. Water, Air and Soil Pollution Focus 4, 9-23.

Galloway, J.N., Dentener, F.J., Capone, D.G., Boyer, E.W., Howarth, R.W., Seitzinger, S.P., Asner, G.P., Cleveland, C.C., Green, P.A., Holland, E.A., Karl, D.M., Michaels, A.F., Porter, J.H., Townsend, A.R., Vörösmarty, C.J., 2004. Nitrogen cycles: past, present and future. Biogeochemistry 70, 153-226.

Galloway, JN., Townsend, A.R., Erisman, J.W., Bekunda, M., Cai, Z., Freney, J.R Martinelli, L.A., Seitzinger, S.P., Sutton, M.A., 2008. Transformation of the nitrogen cycle: recent trends, questions and potential solutions. Science 320, 889-892.

Garten, J.R., Hanson, P.J., 1990. Foliar retention of $15 \mathrm{~N}^{-\mathrm{NO}_{3}}{ }_{3}^{-}$and $15 \mathrm{~N}-\mathrm{NH}_{4}^{+}$by red maple (Acer rubrum) and White oak (Quercus alba) leaves from simulated rain. Environmental and Experimental Botany 30, 333-342.

Gerendas, J., Ratcliffe, R.G., 2000. Intracellular $\mathrm{pH}$ regulation in maize root tips exposed to ammonium at high external pH. Journal of Experimental Botany 51 207-219.

Ghnaya, T. Slama, I., Messedi, D., Grignon, C., Ghorbel, M.H., Abdelly, C., 2007. Effects of $\mathrm{Cd}^{2+}$ on $\mathrm{K}^{+}, \mathrm{Ca}^{2+}$ and $\mathrm{N}$ uptake in two halophytes Sesuvium portulacastrum and Mesembryanthemum crystallinum: consequences on growth. Chemosphere 67, 72-79.

Gloser, V., Gloser, J., 2000. Nitrogen and base cation uptake in seedlings of Acer pseudoplatanus and Calamagrostis villosa exposed to an acidified environment. Plant and Soil 226, 71-77. 
Hauck, M., 2010. Ammonium and nitrate tolerance in lichens. Environmental Pollution 158, 1127-1133.

Hautier, Y., Niklaus, P.A., Hector, A., 2009. Competition for light causes plant biodiversity loss after eutrophication. Science 324, 636-638.

Hogan, E.J., Minnullina, G., Sheppard, L.J., Leith, I.D., Crittenden, P.D., 2010. Response of phosphomonoesterase activity in the lichen Cladonia portentosa to $\mathrm{N}$ and $\mathrm{P}$ enrichment in a field manipulation experiment. New Phytologist, 911-925.

Holland, E.A., Braswell, B.H., Sulzman, J., Lamarque, J.F., 2005. Nitrogen deposition onto the United States and Western Europe: synthesis of observations and models. Ecological Applications 15, 38-57.

Houdijk, A.L.F.M., Verbeek, P.J.M., van Dijk, H.F.G., Roelofs, J.G.M., 1993. Distribution and decline of endangered herbaceous heathland species in relation to the chemical composition of the soil. Plant and Soil 148, 137-143.

Jansen, A.J.M., Roelofs, J.G.M., 1996. Restoration of Cirsio-Molinietum wet meadows by sod cutting. Ecological Engineering 7, 279-298.

Keeler, B.L., Hobbie, S.E., Kellogg, L.E., 2009. Effects of long-term nitrogen addition on microbial enzyme activity in eight forested and grassland sites: implications for litter and soil organic matter decomposition. Ecosystems 12,1-15.

Klap, J.M., Schmidt, P., 1995. Measures to counter effects of eutrophication and acidification in forests with special values of nature: description of the initial situation and the implementation of the measures under controlled field conditions on six sites in the Netherlands. Hinkeloord Report No. 13183. Departments of Forestry, Agricultural University Wageningen, Wageningen, The Netherlands.

Kleijn, D., Bekker, R.M., Bobbink, R., De Graaf, M.C., Roelofs, J.G.M., 2008. In search for key biogeochemical factors affecting plant species persistence in heathland and acidic grasslands: a comparison of common and rare species. Journal of Applied Ecology 45, 680-687.

Knorr, W., Prentice, I.C., House, J.I., Holland, E.A., 2005. Long-term sensitivity of soil carbon turnover to warming. Nature 433, 298-302.

Koyama, L., Tokuchi, N., 2003. Effects of $\mathrm{NO}_{3}^{-}$availability on $\mathrm{NO}_{3}^{-}$use in seedlings of three woody shrub species. Tree Physiology 23, 281-288.

Lamers, L.P.M., Bobbink, R., Roelofs, J.G.M., 2000. Natural nitrogen filter fails polluted raised bogs. Global Change Biology 6, 583-586.

Lazof, D.B., Rincon, M., Rufty, T.W., MacKown, C.T., Carter, T.E., 1994. Aluminium accumulation and associated effects on ${ }^{15} \mathrm{NO}_{3}^{-}$influx in roots of two soybean genotypes differing in Al tolerance. Plant and Soil 164, 291-297.

LeBauer, D.S., Treseder, K.K., 2008. Nitrogen limitation of net primary productivity in terrestrial ecosystems is globally distributed. Ecology 89, 371-379.

Limpens, J., Berendse, F., 2003. How litter quality affects mass loss and N loss from decomposing Sphagnum. Oikos 103, 537-547.

Limpens, J., Berendse, F., Klees, H., 2003. N deposition affects $\mathrm{N}$ availability in interstitial water, growth of Sphagnum and invasion of vascular plants in bog vegetation. New Phytologist 157, 339-347.

Löfgren, S., Cory, N., Zetterberg, T., Larsson, P., Kronnäs, V., 2009. The long-term effects of catchment liming and reduced sulphur deposition on forest soils and runoff chemistry in southwest Sweden. Forest Ecology and Management 258, 567-578.

Lucassen, E.C.H.E., Bobbink, R., Smolders, A.J.P., Van der Ven, P.J.M., Lamers, L.P.M., Roelofs, J.G.M., 2003. Interactive effects of low pH and high ammonium levels responsible for the decline of Cirsium dissectum (L.) Hill. Plant Ecology 165, 45-52.

Lumme, I., 1994. Nitrogen uptake of Norway spruce (Picea abies Karst.) seedlings from simulated wet deposition. Forest Ecology and Management 63, 87-96.

Luna, B., Moreno, J.M., 2009. Light and nitrate effects on seed germination of Mediterranean plant species of several functional groups. Plant Ecology 203. 123-135.

Manning, P., Newington, J.E., Robson, H.R., Sauners, M., Eggers, T., Bradford, M.A., Bardgett, R.D., Bonkowski, M., Ellis, R.J., Grange, A.C., Grayston, S.J., Kandeler, E., Marhan, S., Reid, E., Tscherko, D., Godfray, H.C.J., Rees, M., 2006. Decoupling the direct and indirect effects of nitrogen deposition on ecosystem function. Ecology Letters 9, 1015-1024.

Manning, P., Houston, K., Evans, T., 2009. Shifts in seed size across experimental nitrogen enrichment and plant density gradients. Basic and Applied Ecology 10 $300-308$.

Marschner, H., 1995. Mineral Nutrition of Higher Plants. Academic Press, London.

Maskell, L.C., Smart, S.M., Bullock, J.M., Thompson, K., Stevens, C.J., 2010. Nitrogen deposition causes widespread species loss in British habitats. Global Change Biology 16, 671-679.

Mountford, J.O., Lakhani, K.H., Kirkham, F.W., 1993. Experimental assessment of the effects of nitrogen addition under hay-cutting and aftermath grazing on the vegetation of meadows on a Somerset peat moor. Journal of Applied Ecology 30, $321-332$.

Nordin, A., Högberg, P., Näsholm, T., 2001. Soil nitrogen form and plant nitrogen uptake along a boreal forest productivity gradient. Oecologia 129, 125-132.

Paavolainen, L., Smolander, A., 1998. Nitrification and denitrification in soil from a clear-cut Norway spruce (Picea abies) stand. Soil Biology and Biochemistry 30, 775-781.

Palmqvist, K., Dahlman, L., 2006. Responses of the green algal foliose lichen Platismatia glauca to increased nitrogen supply. New Phytologist 171, 343-356.

Paulissen, M.P.C.P., Van der Ven, P.J.M., Dees, A.J., Bobbink, R., 2004. Differential effects of nitrate and ammonium on three fen bryophyte species in relation to pollutant nitrogen input. New Phytologist 164, 451-458.

Pearce, I.S.K., Woodin, S.J., van der Wal, R., 2003. Physiological and growth responses of the montane bryophyte Racomitrium lanuginosum to atmospheric nitrogen deposition. New Phytologist 160, 145-155.
Pearson, J., Stewart, G.R., 1993. The deposition of atmospheric ammonia and its effects on plants. New Phytologist 125, 283-305.

Pearson, J., Soares, A., 1995. A hypothesis of plant susceptibility to atmospheric pollution based on intrinsic nitrogen metabolism: why acidity really is the problem. Water, Air and Soil Pollution 85, 1227-1232.

Pérez-Soba, M., van der Eerden, L.J.M., 1993. Nitrogen uptake in needles of Scots pine (Pinus sylvestris L.) when exposed to gaseous ammonia and $\mathrm{NH}_{4}^{+}$fertilizer in the soil. Plant and Soil 153, 231-242.

Persson, J., Högberg, P., Ekbald, A., Högberg, M., Nordgren, A., Näsholm, T., 2003. Nitrogen acquisition from inorganic and organic sources by boreal forest plants in the field. Oecologia 137, 252-257.

Peuke, A.D., Jeschke, W.D., Dietz, K.J., Schreiber, L., Hartung, W., 1998. Foliar application of nitrate or ammonium as sole nitrogen supply in Ricinus communis - I. Carbon and nitrogen uptake and inflows. New Phytologist 138, 675-687.

Prober, S.M., Thiele, K.R., Lunt, I.D., Koen, T.B., 2005. Restoring ecological function in temperate grassy woodlands: manipulating soil nutrients, exotic annuals and native perennial grasses through carbon supplements and spring burns. Journal of Applied Ecology 42, 1073-1085.

Prosser, J.I., 1989. Autotrophic nitrification in bacteria. Advances in Microbial Physiology 30, 125-181.

Raven, J.A., Smith, F.A., 1976. Nitrogen assimilation and transport in vascular plants in relation to intracellular $\mathrm{pH}$ regulation. New Phytologist 76, 415-431.

Roelofs, J.G.M., Kempers, A.J., Houdijk, A.L.F.M., Jansen, J., 1985. The effect of airborne ammonium sulphate on Pinus nigra var. maritima in the Netherlands. Plant and Soil 84, 45-56.

Roelofs, J.G.M., Boxman, A.W., Van Dijk, H.F.G., 1987. Effects of airborne $\mathrm{NH}_{4}^{\dagger}$ on natural vegetation and forests. In: Asman, W.A.H., Diederen, H.S.M.A. (Eds), Ammonia and Acidification, Symposium EURASAP, Bilthoven, The Netherlands, 13-15 April 1987. RIVM/TNO, Bilthoven, pp. 266-276.

Sanchez-Hoyos, M.A., Manrique, E., 1995. Effect of nitrate and ammonium ions on the pigment content (xanthophylls, carotenes and chlorophylls) of Ramalina capitata. Lichenologist 27, 155-160.

Sanchez-Martin, L., Vallejo, A., Dick, J., Skiba, U.M., 2008. The influence of soluble carbon and fertilizer nitrogen on nitric oxide and nitrous oxide emissions from two contrasting agricultural soils. Soil Biology and Biochemistry 40, 142-151.

Sanger, L.J., Billett, M.F., Cresser, M.S., 1993. Assessment by laboratory simulation of approaches to ameliorate peat acidification. Environmental Pollution 81, 21-29.

Schjoerring, J.K., Husted, S., Mäck, G., Mattsson, M., 2002. The regulation of $\mathrm{NH}_{4}^{+}$ translocation in plants. Journal of Experimental Botany 53, 883-890.

Schortemeyer, M., Stamp, P., Feil, B., 1997. Ammonium tolerance and carbohydrate status in maize cultivars. Annals of Botany 79, 25-30.

Sievering, H., Tomaszewski, T., Torizzo, J., 2007. Canopy uptake of atmospheric N deposition at a conifer forest: part I - canopy $\mathrm{N}$ budget, photosynthetic efficiency and net ecosystem exchange. Tellus Series B - Chemical and Physical Meteorology 59B, 483-492.

Silver, W.L., Herman, D.J., Firestone, M.K., 2001. Dissimilatory nitrate reduction to ammonium in upland tropical forest soils. Ecology 82, 2410-2416.

Singh, B., Amritphale, D., 1992. Effect of light and its interaction with nitrate and ammonium ions in seed germination of Caesulia axillaris. Physiologia Plantarum $85,43-48$.

Stevens, R.J., Laughlin, R.J., Malone, J.P., 1998. Soil pH affects the processes reducing nitrate to nitrous oxide and di-nitrogen. Soil Biology and Biochemistry 30, 1119-1126.

Stevens, C.J., Dise, N.B., Mountford, J.O., Gowing, D.J., 2004. Impact of nitrogen deposition on the species richness of grasslands. Science 303, 1876-1879.

Stevens, C.J., Dise, N.B., Gowing, D.J., 2009. Regional trends in soil acidification and metal mobilisation related to acid deposition. Environmental Pollution 157, 313-319.

Stevens, C.J., Tilman, D., 2010. Point source ammonia emissions are having a detrimental impact on prairie grasslands. Water, Air and Soil Pollution 211, 435-441.

Suding, K., Collins, S., Clark, C., Cleland, E., Gough, L., Gross, K., Milchunas, D., Pennings, S., 2005. Functional and abundance-based mechanisms explain diversity loss due to nitrogen fertilization. Proceedings of the National Academy of Science 102, 4387-4392.

Sutton, M.A., Milford, C., Dragosits, U., Place, C.J., Singles, R.J., Smith, R.I., Pitcairn, C.E.R., Fowler, D., Hill, J., ApSimon, H.M., Ross, C., Hill, R., Jarvis, S.C., Pain, B.F., Phillips, R., Harrison, R., Moss, D., Webb, J., Espenhahn, S.E., Lee, D.S., Hornung, M., Ullyett, J., Bull, K.R., Emmett, B.A., Lowe, J., Wyers, G.P., 1998. Dispersion, deposition and impacts of atmospheric ammonia: quantifying local budgets and spatial variability. Environmental Pollution 102, 349-361.

Taylor, P.G., Townsend, A.R., 2010. Stoichiometric control of organic carbon-nitrate relationships from soils to the sea. Nature 464, 1178-1181.

Teklemariam, T.A., Sparks, J.P., 2004. Gaseous fluxes of peroxyacetyl $\mathrm{NO}_{3}^{-}$(PAN) into plant leaves. Plant, Cell and Environment 27, 1149-1158.

Theobald, M.R., Milford, K.J., Hargreeves, L.J., Sheppard, L.J., Nemitz, E., Tang, Y.S., 2001. Potential for ammonia recapture by farm woodlands: design and application of a new experimental facility. The ScientificWorld 1, 791-801.

Török, K., Szili-Kovacs, T., Halassy, M., Toth, T., Hayek, Z., Paschke, M.W., Wardell, L.J., 2000. Immobilization of soil nitrogen as a possible method for the restoration of sandy grassland. Applied Vegetation Science 3, 7-14.

Treseder, K.K., 2004. A meta-analysis of mycorrhizal responses to nitrogen, phosphorus, and atmospheric $\mathrm{CO}_{2}$ in field studies. New Phytologist 164, 347-355.

Van den Berg, L.J.L., Dorland, E., Vergeer, P., Hart, M.A.C., Bobbink, R., Roelofs, J.G.M., 2003. Decline of acid-sensitive plant species in heathland can be attributed to ammonium toxicity in combination with low pH. New Phytologist 166, 551-564. 
Van den Berg, L.J.L., Dorland, E., Vergeer, P., Hart, M.A.C., Bobbink, R., Roelofs, J.G.M., 2005. Decline of acid-sensitive plant species in heathland can be attributed to ammonium toxicity in combination with low pH. New Phytologist 166 551-564.

Van den Berg, L.J., Peters, C.J., Ashmore, M.R., Roelofs, J.G., 2008. Reduced nitrogen has a greater effect than oxidised nitrogen on dry heathland vegetation. Environmental Pollution 154, 359-369.

Van Leeuwen, E.P., Draaijers, G.P.J., Erisman, E.W., 1996. Mapping wet deposition of acidifying components and base cations over Europe using measurements. Atmospheric Environment 30, 2495-2511.

Vergeer, P., van den Berg, L.J.L., Baar, J., Ouborg, N.J., Roelofs, J.G.M., 2006. The effect of turf cutting on plant and mycorrhizal spore recolonisation: implications for heathland restoration. Biological Conservation 129 226-235.

Vestgarden, L.S., Kjønaas, O.J., 2003. Potential nitrogen transformations in mineral soils of two coniferous forests exposed to different $\mathrm{N}$ inputs. Forest Ecology and Management 174, 191-202.

Walker, K.J., Stevens, P.A., Stevens, D.P., Mountford, J.O., Manchester, S.J., Pywell, R.F. 2003. The restoration and re-creation of species rich lowland grassland on land formerly managed for intensive agriculture in the UK. Biological Conservation 119, 1-18.

Wamelink, G.W.W Goedhart, PW van Dobben, H.F., Berendse, F., 2005. Plant species as predictors of soil $\mathrm{pH}$ : replacing expert judgment by measurements. Journal of Vegetation Science 16, 461-470.

Webster, G., Embley, T.M., Freitag, T.E., Smith, Z., Prosser, J.I., 2005. Links between ammonia oxidizer species composition, functional diversity and nitrification kinetics in grassland soils. Environmental Microbiology 7, 676-684.

Wilson, E.J., Wells, T.C.E., Sparks, T.H., 1995. Are calcareous grasslands in the UK under threat from nitrogen deposition? - an experimental determination of a critical load. Journal of Ecology 83, 823-832.

Wiedermann, M.M., Gunnarsson, U., Nilsson, M.B., Nordin, A, Ericson, L, 2009. Can small-scale experiments predict ecosystem responses? An example from peatlands. Oikos $118,449-456$.

Wilson, E.J., 1992. Foliar uptake and release of inorganic nitrogen compounds in Pinus sylvestris L. and Picea abies (L.) Karst. New Phytologist 120, 407-416.

Yoshida, L. C. Allen, E.B., 2001. Response to ammonium and nitrate by a mycorrhizal annual invasive grass and native shrub in southern California. American Journal of Botany 88, 1430-1436. 